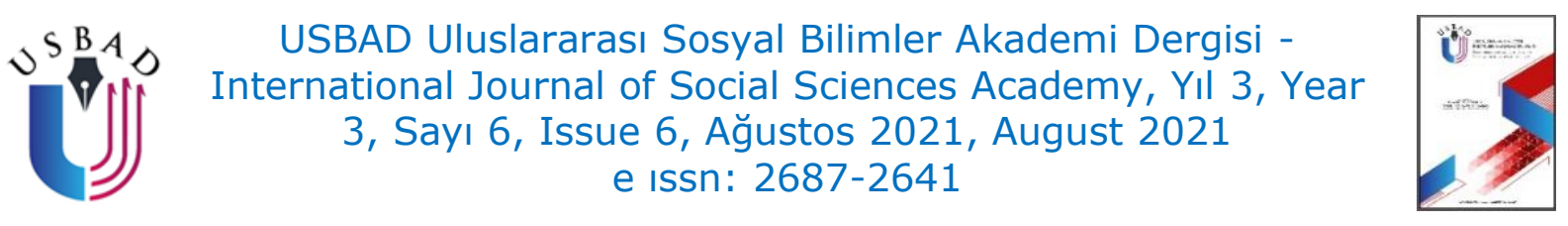

\title{
KORKU FİLMİ ÖZELINNDE VR SİNEMASI ÇÖZÜMLEMESİ: THE CONJURING 2: VR EXPERIENCE VE THE FOREST - 360 EXPERIENCE
}

VR CINEMA ANALYSIS SPECIFIC TO HORROR FILM:

THE CONJURING 2: VR EXPERIENCE AND THE FOREST - 360 EXPERIENCE

\author{
Sercan KULE \\ Doktora Öğrencisi, Yıldız Teknik \\ Üniversitesi, Sosyal Bilimler \\ Enstitüsü, Sanat ve Tasarım, \\ İstanbul/Türkiye \\ Ph.d., Yildiz Technical University, \\ Graduate School of Social Sciences, \\ Art and Design, \\ İstanbul/Turkey. \\ sercankule@gmail.com
}

ORCID ID: 0000-0002-6128-3046

\section{Lütfü KAPLANOĞLU}

Doç. Dr., Yıldız Teknik Üniversitesi, Sanat ve Tasarım Fakültesi, Sanat Bölümü, Birleşik Sanatlar Anasanat Dalı, İstanbul/Türkiye Assoc. Prof., Yildiz Technical University, Faculty of Art \& Design, Department of Arts, Combined Arts, İstanbul/Turkey.

Ikaplanoglu@gmail.com

ORCID ID: 0000-0002-7094-8302

\author{
Makale bilgisi | Article Information \\ DOI: $10.47994 /$ usbad.951034 \\ Makale Türü / Article Type: Araştırma Makalesi / Research Article \\ Geliş Tarihi / Date Received: 11.06.2021 \\ Kabul Tarihi / Date Accepted: 28.07.2021 \\ Yayın Tarihi / Date Published: 20.08.2021 \\ Yayın Sezonu / Pub Date Season: Ağustos / August
}

Bu Makaleye Atıf İçin / To Cite This Article: Kule, S. \& Kaplanoğlu, L. (2021). Korku Filmi Özelinde VR Sineması Çözümlemesi: The Conjuring 2: VR Experience ve The Forest - 360 Experience. USBAD Uluslararası Sosyal Bilimler Akademi Dergisi 3(6), 1159-1189.

Intihal: Bu makale intihal.net yazılımınca taranmıştır. İntihal tespit edilmemiştir.

Plagiarism: This article has been scanned by intihal. net. No plagiarism detected.

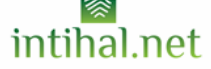

İletişim: Web: https://dergipark.org.tr/tr/pub/usbad mail: usbaddergi@gmail.com 
Öz: Lumiere kardeşlerin yaptığı trenin gara girişi filminden itibaren sinema, düşler perdesindeki bir illüzyondur. Bu illüzyon ise hiç durmadan devam etmektedir ve yıllar geçtikçe her yeni teknolojik gelişme sinemada da yerini almaktadır. Bu gelişmelerin sonuncusu ise sanal gerçeklik teknolojisi olarak kabul edilebilmektedir. Sanal gerçeklikle birlikte sanat sergileri, konserler, turistik, eğitim, askeri ve oyun gibi alanların yanında sinemada da örnekler mevcuttur. Sanal gerçekliği de bir illüzyon olarak görecek olursak, kendisi de bir illüzyon sanatı olan sinemadaki varlığı merak uyandırıcıdır. Bu çalışma sanal gerçekliğin sinemadaki izini sürerek, yapılan korku VR filmleri olan The Conjuring 2: VR Experience ve The Forest - 360 Experience'ı örneklem alıp çözümleme yoluna gitmeyi amaçlamaktadır. Göstergebilimden yararlanarak gerçekleştirilecek olan çözümlemede sinemadaki korkunun psikoloji yönünden de ele alınarak izleyici tarafındaki algılanmasına değinilecektir. Son yıllardaki teknolojik gelişmeler ve VR ürünlerinin ev kullanıcısı için uygun hale gelmesi ilgiyi arttırmaktadır. Sinema ve VR arasındaki oluşan bu yeni ortaklık üzerine bilinmezlik ve çalışmaların az olması çalışmanın önem kısmını teşkil etmektedir.

Anahtar Kelimeler: Sanal Gerçeklik, Korku Sineması, Gerçekçilik, Göstergebilim

Abstract: Cinema has been an illusion in the curtain of dreams since The Arrival of a Train at La Ciotat Station which was made by the Lumiere brothers. This illusion continues unabated and every new technological development takes its place in cinema over the years. The last of theses developments can be considered as virtural reality techology. Along with virtual reality, there are examples in cinema as well as in areas such as art exhibitions, concerts, tourism, education, military and games. If we consider virtual reality as an illusion, its presence in cinema, which is itself an illusion art, is intriguing. This study aims to analyze the horror VR movies which are The Conjuring 2: VR Experience and The Forest - 360 Experience by following the traces of virtual reality in cinema. In the analysis which will be carried out by making use of semiotics, the perception of fear in the cinema by the audience will be discussed by considering the psychology aspect. Technological developments in the recent years and the fact that VR products are suitable for home users increase the interest. The obscurity and the scarcity of studies on this new partnership between cinema and VR constitue the important part of the study.

Key Words: Virtual Reality, Horror Film, Reality, Semiology

\section{GİRiş}

Sinema, bir hikaye anlatma aracıdır. Bu hikayeyi anlatırken de görsel gücünden yararlanmaktadır. 1895 yılında Lumiere kardeşlerin trenin gara girişi filminin gösteriminde trenin kendi üzerlerine gelişini gerçek sanan insanlar bir nevi sanal deneyim yaşarlar. İster evde isterse sinema salonunda olsun; monitör, televizyon ya da sinema projektörü aracılığıyla sinemanın sunduğu sanal deneyim devam etmektedir. Sanal gerçeklik 
cihazlarının sunduğu olguyu, monitörü sanal alanın bir parçasıymışsınız gibi çalışacak bir cihaz haline getirmektir (Zarka ve Shah, 2016: 62). Son yıllardaki teknolojik gelişmeler ve VR ürünlerinin ev kullanıcısı için uygun hale gelmesi ilgiyi arttırmaktadır. Sinema ve VR arasındaki oluşan bu yeni ortaklık üzerine bilinmezlik ve çalışmaların az olması çalışmanın önem kısmını teşkil etmektedir. Hem sinemanın ve hem de sanal gerçekliğin teknolojik gelişmeler sonucunda günümüzdeki hallerini alması sonucu, aralarındaki etkileşimin nasıl olduğu, sanal gerçekliğin sinema açısından gerçeklik anlatısını ne şekilde etkilediği, gerçekçiliği anlatımında ön plana çıkaran korku türünde de sanal gerçeklik teknolojisinin ne konumda olduğu soruları çalışma kapsamında cevaplanmaya çalışılacaktır. Bu çalışma sanal gerçekliğin sinemadaki izini sürerek, yapılan korku VR filmleri olan The Conjuring 2: VR Experience ve The Forest - 360 Experience'ı örneklem alıp her ikisini de çözümleme yoluna gitmeyi amaçlamaktadır. Sanal gerçeklik, sinema ve korku türü ekseninde örneklerin sayılı olması nedeniyle, aynı yıl içerisinde üretilen bu örneklemler ele alınmaktadır. Göstergebilimden yararlanarak gerçekleştirilecek olan çözümlemede sinemadaki korkunun psikoloji yönünden de ele alınarak izleyici tarafındaki algılanmasına değinilecektir.

Sanal gerçeklik (Virtual Reality), gerçek dünyaya benzer ya da Sayfa | 1161 tamamen farklı olabilen simüle edilmiş bir bilgisayar teknolojisi deneyimidir. Sanal gerçeklik, altyapısını kullanan uygulamalar sayesinde turizmden eğlenceye, mimari yapıların tasarımından sanat turlarına kadar çeşitli alanlarda varlık göstermektedir. Farklı sanal gerçeklik (VR) teknoloji türleri arasında, bazen genişletilmiş gerçeklik ya da artırılmış gerçeklik de olarak bilinen AR ve genişletilmiş gerçeklik (Extended Reality: XR) yer alır. İki tür VR arasında ayrım yapılmaktadır. Bunlar sürükleyici VR ve metin taban bağlantılı VR (Cyberspace olarak da adlandırılır) şeklindedir. Her iki VR çeşidi de alıştırma için uygun olsa da uzaktan eğitim için Cyberspace tercih edilmektedir (Psotka, 1995: 405-431).

Günümüzde standart sanal gerçeklik sistemleri, bir kullanıcının sanal bir ortamda fiziksel varlığını simüle eden gerçekçi görüntüler, sesler ve diğer duyu organlarını harekete geçirebilmek için ya sanal gerçeklik başlıklarını ya da çoklu projeksiyonlu ortamları kullanmaktadır. Bu ekipmanı kullanan birisi, yapay dünyada çevresine bakabilir, içinde hareket edebilir ve sanal özellikler ya da öğelerle etkileşime girebilir. Etki genellikle, gözlerin önünde küçük bir ekrana sahip başa takılan VR başlıklarıyla oluşturulur. Fakat birden fazla geniş ekranlara sahip özel olarak tasarlanan odalar vasıtasıyla da oluşturulabilmektedir. Sanal gerçeklik genel olarak işitsel ve video geri 
bildirimini içerirken haptik teknoloji* / kinestetik iletişim aracılığıyla diğer duyusal geri bildirimlerine de sahiptir.

$\mathrm{Bu}$ noktada, sanal gerçekliğin sinemadaki ağırlığı tam olarak hissedilmemektedir. Bunun nedeni teknolojinin ev kullanıcısı için uygun fiyata yeni yeni gelmesi gösterilebilir. Cihazların gelişimi de 1962 yılında geliştirilen ve ilk cihaz olarak kabul edilen devasa The Sensorama'nın yanında oldukça kullanılabilir duruma gelmektedirler. Günümüzde bu cihazlar Hollanda, Almanya ve Amerika gibi ülkelerin sinema salonlarında da kendine yer bulmaktadırlar. Sanal gerçekliğin kesin kökenleri, varlığına ait kesin bir tanım oluşturmanın zorluğundan dolayı tartışılmaktadır (Schnipper, 2020). Sanal gerçekliğin diğer unsurları 1860'larda görülebilir. İllüzyonun, gerçeklikten farklı olmadığı görüşü benimsenerek, izleyicilerin şüpheciliğini bir anlığına bırakılmasının istendiği oyunda ve sahnedeki dramayı gerçeklik olarak algılaması gerektiği savunulmaktadır (Artaud, 1958). Sanal gerçekliğin daha modern referansları bilim kurgudan gelmektedir. Morton Heiling, 1950'lerde tüm duyuları etkili bir şekilde yansıtabilecek ve izleyiciyi ekrandaki etkinliğin içine çekebilecek 'Deneyim Tiyatrosu" adını verdiği vizyonunu ortaya koyar. Bu vizyonunu biraz önce andığımız gibi 1962 yılında, The Sensorama ile vizyonunun bir örneğini ve onunla birlikte gösterilecek beş kısa filmi yapar. The Sensorama, Sayfa| 1162 stereoskopik renkli ekran, stereo ses sistem, koku yayıcılar, fanlar ve hareketli koltuğa sahip mekanik bir cihazdır (Regrebsubla, 2015: 5). New York'taki bir motosiklet yolculuğu gösterilirken biryandan da izleyicinin deneyimleyebilmesi için hayali bir motosikletin içinde oturur, ekrandan caddeyi, fanın oluşturduğu rüzgârı ve şehrin simüle edilmiş gürültü ve kokusunu tecrübeler. Bu öğeler, izleyici bir otobüse yaklaştığında egzoz kimyasallarının salınması gibi uygun anda tetiklenir (Craig vd., 2009: 4). Bunun gibi kokular da kimyasallarla yeniden yaratılır (Grau, 2003: 1786). 1968 yılında, Ivan Sutherland -bilgisayar grafiklerinin babası- kapsamlı simülasyon uygulamalarında kullanabilmek için ilk başa takılan ekran sistemini yapar. Giyilecek başlığın ağır olması sebebiyle tavana asııması gereken sistem, kullanıcı ara yüzü ve görsel gerçeklik bakımından ilk olmaktadır. Cihazın bu görünümünden dolayı da "Demokles'in Kılıcı" adını alır (Sutherland, 1968). David Em, NASA'da 1977 ile 1984 yılları arasında gezinebilir sanal dünyalar üreten ilk sanatçı olur (Nelson, 1982). Bu yıllarda, oyun ve eğitim için çalışmalara da ağırlık verilir. Autodesk'teki Cyberspace projesi, sanal gerçekliği kişisel bilgisayarlara taşımayı başarır (Barlow,

\footnotetext{
${ }^{*}$ Kullanıcıya titreşim, hareket ya da kuvvet uygulanması yoluyla dokunma deneyimi yaratabilen teknolojiyi ifade etmektedir.
} 
1990). 90’larda tüketici odaklı başlıkların ilk yaygın ticari sürümleri görülür. Oyun konsol üreticisi ve yapımcısı SEGA, Sega VR başlığını çıkarır. Carolina Cruz-Neira'nın doktora tezinden geliştirilen ve Carolina Cruz-Neira, Daniel J. Sandin ve Thomas A. DeFanti tarafından üretilen CAVE, kübik bir odadaki otomatik sanal ortamdır (Cruz-Neira vd., 1992). Proje, odanın duvarlarına görüntülerin projektörlerle yansıtılması vasıtasıyla gerçekleşir. 2010'lu yıllarda sanal gerçeklik başlıkları alanında Oculus Rift'le başlayan süreç, HTC Vive, PlayStation VR, bir kendin yap stereoskopik görüntüleyici olan ve kullanıcının akıllı telefonunu karton tutucu kısma yerleştirip kafasına taktığı Google Cardboard, OSVR ve şu an üretimi durdurulan Samsung Gear VR gibi örneklerle devam etmektedir. 2020 yılındaki COVID-19 kısıtlamaları ile VR pazarı büyük bir artış yaşamaktadır. Küresel sanal gerçeklik pazarı 2027 yılında 62,1 milyar dolara ulaşacaktır. 2020 ile 2027 yılları arasındaki süreçte, pazar araştırmacıları yıllık \%20'nin üzerinde bir büyüme oranı beklemektedir (Jochum, 2020).

Sinema, fotoğrafla yolculuğuna başlar. Sinema da fotoğrafın kullanım aracı gibi zamanını, kültürel ve toplumsal öğeleri bir nevi belgeleyip onları unutulmaz kılan bir iletişim aracıdır. Fotoğraf gibi sinemanın da dili görüntülerdir. Bu görüntüler de birleştiğinde bir gösterge meydana gelmektedir. Göstergeler, bulunduğu toplumun içinde görünenlerin, Sayfa | 1163 nesnelerin ve soyut kavramların vücut bulmuş halidir (Lotman, 2012: 13). Göstergelerin ise gerçek veya alt anlamları bulunmaktadır. Anlamlar yoluyla da gerçek ortaya çıkarılmaya ya da yorumlanmaya çalışılır.

Gösteren ve gösterilenden oluşan gösterge, anlam aktarıcı birleşimi belirtmek için, bir neden olacağından dolayı, bir gösteren ve bir gösterilenden veya bir işitim imgesiyle bir kavramın oluşumudur (Barthes, 2005: 48). Gösteren ve gösterilenden oluşan göstergeler, günlük hayattaki herhangi işaret vasıtasıyla bir göndermeye ve duruma işaret edebilmektedir. Bu işaretler yoluyla da insanlar, nesnelere anlamlar yüklemektedir.

Gösterenler anlatım düzlemini oluştururken, gösterilenler ise içerik düzlemini oluşturarak; her düzlem de biçim ve töz olmak üzere iki katmandan meydana gelmektedir. Biçim, dilbilim dışı hiçbir ön şarta başvurmadan dilbilimin tümünü kapsayıcı, yalın ve tutarlı bir biçimde betimleyeceği olgularken; töz ise dilbilim dışı ön şartlara başvurmadan betimlenemeyecek dilsel özelliklerin tamamıdır (Barthes, 2005: 48). Göstergebilimsel dizgelerin çoğu, nesneler, vücut hareketleri, görüntüler gibi varlığı anlamlandırmada yer almayan bir anlatım tözü içerirken: giysinin korunmaya, besinin beslenmeye, yağmurluğun yağmurdan korunmaya 
yaradığı toplum tarafından, anlamlanma amacıyla türetilen kullanım nesneleridir (Barthes, 2005: 49). Yağmurluk aynı zamanda hava durumunu da belirten bir göstergedir. Saussure'nin örneği temel alınırsa, limon sözcüğü bir gösterge, l-i-m-o-n harflerinden oluşan yazılı veya işitsel imge gösteren, zihinde oluşturduğu limon kavramı ise gösterilen şeklindedir.

Göstergebilim, dillerin, simgelerin ve normların gösterge oluşturacak şekilde bütününü incelemektedir (Guirand, 1994: 17). Göstergebilim, görünen simgelerin dışında, sosyolojik değer taşıyabilecek durumlara geçilince tekrar dille karşılaşmaktadır. Görüntüler, davranışlar ve nesneler anlam taşır; ancak bunlar bağımsız olmak yerine gösterge bütünlüğü içinde dille birleşmektedir (Barthes, 2005: 28). Anlamlandırma iki yüzeye sahiptir. Düz anlam, gerçek dünyada bulunan nesnenin zihinde oluşturabildiği yansımasıdır. Göstergenin belirli bir düz anlamı bulunur ve gösteren ile arasında bağlantı olması gerekmektedir. Yan anlam ise, göstergenin izleyici tarafından heyecan ve kültürel benlikleriyle buluştuğundaki etkileşim durumudur (Barthes, 2005: 50-51). Sinemada bu anlamlandırma ise, görüntünün görünen anlamı haricinde, izleyicinin benliğinde toplumsal ve kültürel ölçütleriyle etkileşimde bulunarak farklı anlamlar ve yorumlamalar yoluna gitmektedir.

Sinema, kendini ifade edebilmek için kendine ait bir dil kullanır. Bu Sayfa | 1164 dilde de sinemanın en küçük birimi olan çekim bir sözcüğe değil, tümceye benzetilmektedir (Metz, 1985a: 218). Bir objenin görüntüsü, sinema dilinde bir özne ya da nesne değil, direkt olarak tümcedir. Sinema dili de görüntülerin ve seslerin anlam üretilmesi adına birleştirilmesiyle oluşmaktadır. Anlamların üretilmesi adına göstergeler aracılığıyla kodlar oluşturulmaktadır. Anlamlar, kodlar aracılı̆ıyla iletilir. Mesajı seyirciye ileten görsel imge, konuşma, müzik, ses ve yazıdan oluşan beş sinemasal kodlama yolu saptanmaktadır (Metz, 1985b: 227). Bu beşlinin birleşerek anlatım aracı olan sinemada yer bulan kodlar ise üç türde toplanmaktadır. Sinemaya özgü kod, planlarda kullanılan kurgu teknikleridir. Sinemaya ait olmayan kod, sosyolojik mesaja sahiptir. Diğer sanat dallarıyla etkileşim halinde kod ise sinemanın öbür sanat dallarıyla paylaştığı koddur. Kodların çözümlenmesiyle meydana gelen göstergebilimsel eleştiri de gösteren kodların estetik, psikolojik, sosyolojik ve kültürel anlamlara göre belirtilenlerin çözümlendiği birinci düzey ve kodlar yoluyla sunulan sinemasal tarzın incelendiği ikinci düzey şeklinde incelemektedir (Eberwein, 1990: 132). Filmler, anlamın ortaya çıkartılmasını sağlayan değerlendirme ölçütlerinin bulunmasıyla tüketimi biten bir nesne olmaktan çıkarak anlamın filmi yapanların dışında yeniden üretilebildiği bir yapı kazanır (Özden, 2014: 
140). Buradan da yola çıkarak, göstergebilim bir nevi bir filme ömür biçilmesinin önüne geçer. Filmi dönemiyle ele alıp değerlendirebilirken; aynı zamanda film için farklı zaman dilimlerinde farklı okumalar yapılabilmesine de olanak tanır.

\section{GERÇEKLİK, GERÇEKÇİLİK VE SİNEMA}

Gerçeklik günümüzde sorgulanır duruma gelen bir kavramdır. Hakikati aramak sözünü sık sık duyarız. Fakat gerçeklik ya da hakikat açıklanmaya çalışıldığında net bir tanım yapılamadığının da farkına varılabilir. Gerçeklik, kişiden kişiye değişen göreceli bir kavram konumundadır. Bu kavrama dair arayışlar sürekli devam eder. İnsan, dünya üzerindeki varlığı süresince temel ihtiyaçları sonrasında kendini ve çevresini anlamlandırmaya, bunu bir konum içerisine yerleştirebilmeye ve benliğini bunun üzerine temellendirmeye çalışır. Bu temellendirme için gerekli olan temel taş ise gerçeklik olgusudur. Gerçeklikle kendini var eden insan, bu algısını yitirdiği anda bir nevi benliğini de yitirir. Benliği buna temellidir ve bu temel çöker. Gerçekliğin arayışı ve buna merakı da buradan meydana gelir. Günümüzde de yeni teknolojiler ekseninde meydana gelen gerçeklik terimleri, kendini sanal gerçeklik, artırılmış gerçeklik, karma gerçeklik, genişletilmiş gerçeklik gibi (Aydoğan ve Kaplanoğlu, 2020: 82) yeni tanımlarla biçimlenip var eder. Artırılmış Gerçeklik (AR), dünyada bulunan nesnelerin görsel, işitsel, dokunsal ve koku alma gibi birden çok duyusal çalışmada bilgisayar tarafından üretilen algısal bilgilerle genişletilen gerçek dünya ortamıyla etkileşim halindeki bir deneyim sunar. Kısacası gerçekliğin değiştirildiği ve zenginleştirildiği bir ortam sunar. Teknolojik ilerleme beraberinde sanal dünya kavramını da beraberinde getirir. Arttırılmış gerçekliğin üç temel özelliğinden bahsetmek, onu ifade etme açısından önem teşkil eder. Gerçek ve sanal dünyaların birlikteliği, gerçek zamanlı etkileşim ve sanal ile gerçek nesnelerin 3D kaydıdır (Wu vd., 2013: 41-49). Artırılmış gerçeklik, bu yeni dünyanın bileşenlerinin kullanıcı açısından gerçek dünya algısına sadece bir veri sunumu olarak değil, aynı zamanda çevrenin doğal parçaları olarak algılanan kapsayıcı hislerin bütünleştirici karışımıdır. Bu birliktelik, gerçek çevreyle bir algılanarak fiziksel dünya ile etkileşimini kurarak iç içe geçer. Artırılmış gerçeklik, insanın süregiden gerçek dünya algısını değiştirir. Sanal gerçeklikten farkı gerçek dünyayı kullanır, sanal gerçeklik gibi tamamen tasarlanmış bir ortamla değiştirmez. Karma gerçeklik (Mixed Reality: MR), fiziksel ve dijital nesnelerin beraber bulunduğu ve aynı anda etkileşime girilebilen yeni alanlar ve görseller üretmek adına gerçek ile sanal dünyaların kaynaşmasıdır. Karma gerçeklik sadece fiziksel ya da sadece sanal dünyada bir başına olmaz, bu ikisi bir 
yüzey haline getirilerek tek bir dünya halinde varlık gösterir. Askeri eğitim, uzaktan çalışma ve eğitim gibi alanlarda karma gerçeklik uygulamaları mevcuttur. Genişletilmiş gerçeklik (Extended reality: XR), bilgisayar teknolojisi ve giyilebilir cihazlar tarafından bütün gerçek ve sanal ortamlar ile insan-teknoloji etkilemişini ifade eder. Genişletilmiş gerçeklik, artırılmış gerçeklik, karma gerçeklik ve sanal gerçeklik formlarını ve aralarındaki eklemeleri kapsar (Gownder vd., 2016: 2). Bu gerçeklikte, tek tek olan diğer gerçekliklerin hepsini kapsar ve onları ileri taşıyarak tasarımı gerçekleştirip, tasarımın en küçük detayına kadar inceleyebilme imkânı da sunar. Günümüzde an itibariyle eğlence, pazarlama, emlak, eğitim ve uzaktan çalışma alanlarında varlığını gösterir.

İnsanlar kendilerini adeta baştan yaratıp var ettikleri ve bununla da yetinilmeyip kültür ve sanat için de bu dünyada anlam bulan bir yer halini alır. Artık gerçeklik sadece dünyadaki olanlar ve oradaki kurallar değildir. Sanal dünya gerçekliği de vardır. Gerçeklik, düşünülebilen ve biçimlenebilenin tersine, gerçekte var olan ve varlığı anlamlandırmadan bağımsızdır. Gerçek ya da gerçeklik bilinçten, düşünceden ve kurgulanmış olandan bağımsız olarak vücut bulur (Türk, 2014: 15). Buradan hareketle de gerçeklik, tek bir doğruya indirgenemez ve onu sadece fiziksel dünyayla değil tasarımsal ve imgelerden oluşan dünyada da anmak gerekir. BuSayfa| 1166 gerçeklikte duyularımız tarafından gerçekten oradaymış hissinin deneyimlendiği alan olan sanal bir ortam yaratılır (Scales, 2018: 68). Bu gerçeklikte gerçek yeni bir alan bularak, başa geçirilen ekranlar, dokunsal eldivenler, hareketlerin takip edilebildiği sensör cihazlarıyla bu dünya içerisinde etkileşim sağlanan bilgisayar tabanlı bir arayüzdür (Buzjak ve Kunica, 2008: 111). Bu teknolojik imkânlarla insan, benliğinde yatan keşfetme ve ifade etme arzusuyla, bu ortamda da eserler üretmeye veya buraya yönelik eserler yapmaya başlar. Bu yeni gerçeklikteki sanatı, dünyadaki sanattan ayırmamız mümkün değildir. Fiziksel olmaması onu sorgulatabilir konuma indirgemez. Sanat, fiziksel bir forma bağlı değildir. Yukarıda da belirtildiği gibi gerçeklik tamamen tek bir düzlemde konumlandırılmamaktadır. Bir nevi sözü edilen iki gerçeklik birbirlerine bağlı ve etkileşim halindedirler. Buradan yola çıkarak da insan yeni bir gerçeklikte kendini var eder. Bu yeni imkânlar, sanatın ifadesi konusunda yeni araçlara dönüşür. Dünyadan kendi dilediği süre için adeta ayrılan insan, sanal gerçeklik ortamında fiziksel dünyanın ve ona ait birtakım verilerin birebir benzetişimi gibi (Aydoğan ve Kaplanoğlu, 2020: 84) ya da hayal gücünün gittiği yere kadar deneyimi ve gerçekliği yaşar. 
Gerçeklik ve sanal gerçeklik kavramları sonrasında, bunların sinemayla olan ilişkisini ve sinemadaki gerçeklik olgusuna da çalışmanın bu kısmında değinilmesi gerekmektedir. Sinema ve gerçeklik ilişkisine bakıldığında, ilk film örneği olan Lumiere kardeşlerin yaptığı trenin gara girişi bunun en güzel örneğini teşkil eder. Bu gösterim sırasında, insanların izlediklerini gerçek sanarak gösterimin yapıldığı kafeden çıkmaları, sinemanın o zamandan itibaren hem sanat olarak hem de iletişim aracı olarak ne kadar etkin bir öneme sahip olacağını vurgular niteliktedir. Sinemayı gerçekliğin yeniden üretiminin büyülü bir imkânı olarak görüp yalnızca olayları kameraya kaydettiler (Monaco, 2005: 271). Teknolojik ilerlemeler sonucu fotoğrafla başlayan süreç, harekete sahip olmayan fotoğraf karelerinin ardı ardına ve bir saniyede seyre dönüştürülmesiyle, izleyenlerde hareket yanılması sağlayarak sinema için gerçekliğin sorgulanmasının başladığı an çıkarımı yapılabilir. Gözün ağtabaka bölgesinde oluşan iki boyutlu görüntüler, görüntü kaynağı ortadan kalktıktan sonra saniyenin $1 / 10$ kadar bir süre daha aynı bölgede kalabilmektedir (Çınar, 2008: 36). 1829 yılında Joseph Ferdinand Antoine Plateau tarafından yapılan bu keşif, gözün bir redüksiyonu düşünülerek, bu özellik sayesinde hareketli görüntülerin oluşturulması mümkün olmaktadır (Vardar, 2000: 21). Küçük bir özelliğin kullanılmasıyla fotoğraf karesi Sayfa| 1167 üzerinden oluşturulan bu hareket hissiyatı, sinemada gerçekliğin saptırıldığı bir başka yerdir. Sinema bir illüzyondur. Sinema canlı ve çarpıcı bir betimleme, bir ayna işlevi gören bir şeydir (Baudrillard, 2011: 72). İzleyen olarak insanlar bu büyüye kapılıp sinema salonunda, televizyondan, bilgisayarından, cep telefonundan ya da günümüzün son teknoloji ürünü olan VR setinden izliyor olsunlar, bulunduğu alandan kopup filmi adeta yaşamaya başlamaktadırlar. Gerçek hayattan alınıp sahnelenen bir olayın ekranda asıl olayın kendisinin doğrudan kamerayla kaydedilebilecek halinden daha güçlü bir gerçeklik etkisi vermesi mümkündür (Kracauer, 2015: 116). Sinemayı ilginç kılan ve kendisine hayran bıraktırdığı yer tam olarak burasıdır. İzleyici, belki de görmediği ve hissetmediği anlara sinema sayesinde sahip olur. Filmle ağlar, güler, heyecanlanır, sever ve korkar. Bu duyguları sadece filmin iyi hazırlanılmasına bağlayamaz; onun gerçeklik etkisini yadsıyamayız. Sanatta gerçeklik, dünyanın somut bir şekilde ifade edilmesidir (Bazin, 2011: 18). Geleneksel sanatlar kendilerine has araçlarla hayatı dönüştürmek adına varlıklarını sürdürürken, sinema yalnızca hayatı olduğu gibi gösterdiğinde en derin ve en özlü biçimde var olabilmektedir (Andrew, 2010: 193). İlk zaman filmlerini yalın anlatımlarıyla gerçekçilik eğiliminin izleri direkt fark edilirken, günümüze doğru göreceğimiz eserlerde hem gerçekçiliğin hem de biçimciliğin ağır bastığı gözlemlenir. Fakat 
filmlerde biçimlendirme eğilimi baskınken gerçekçilik eğiliminden sıyrılmaya ya da onu büsbütün kapsamaya çalışmaz (Kracaucer, 2015: 520). Yönetmenlerin gerçekliğe dair kendi bakış açılarını yansıtmak zorunda oldukları yorumunda bulunulabilir. Sadece biçimcilik sinemaya zarar verir, onu değiştirir. Baskın olanın gerçekçiliğin olmasıyla birlikte, yönetmen hem gerçekçi hem biçimci olmalı; gerçekliği kaydederek onun iç yüzünü ortaya çıkarabilmeli; gerçekliği içine almalı ve bu sayede ona nüfuz edebilmelidir (Andrew, 2010: 200).

Geri dönersek eğer, gerçekçilik sinema tarihinin ilk kırk yılı boyunca sinema uygulamalarında genel olmasa da yaygındır. Fakat 1930'ların sonunda John Grierson'un önderi olduğu İngiliz belgeselcilerin yapıtlarının ortaya çıktığı dönem ile 1940'lardaki İtalyan Yeni Gerçekçiliği'ne kadar kuramsal olarak bir yer bulamaz (Monaco, 2005: 374). Nedenleri olarak, gerçekçiliğin sinema sanatından daha önemli olduğu algısı, yönetmen ve kuramcı cephesinde onların dışavurumculuğa yönelmelerine sebebiyet verir. Bir nevi varoluş krizindeki sinema, karşılaştırıldığı resim sanatı gibi kendini gösterebilmek ve önemini ortaya koyabilmek adına dışavurumculuğa yönelerek, yönetmeninin yönetimini ön plana koyarak görevini yerine getirir. Gerçekçi kuram, izleyiciyi sürece bir katılımcı olarak konumlandırır (Monaco, 2005: 374). Fakat sinemanın bu ilk çıktığı yıllarda, Sayfa | 1168 pahalı olması nedeniyle sinemanın popüler bir biçim kazanması gerekliliği meydana gelir. Filmin önemi, tüketici olarak konumlanan izleyicinin harcayacağı parayla kıyas edilir. Ne kadar hasılat elde ediyorsa film, o kadar değerlidir. Şeytan (The Exorcist, 1973), Jaws (1975) ve Terminatör 2 (1991) gibi filmler bu kurala göre değerlendirilir ve bu filmlerin başarısı bunu kanıtlar (Monaco, 2005: 374). Sinemada gerçekçilik üzerine sorular durmadan devam eder. Bunun nedeni olarak cevapların muğlaklığı ve tatmin edici olmaması görülebilir. Buradan hareketle Bazin, sinemadaki gerçekliği, sürekli ona yaklaşılan, bağımlı olunan ama hiçbir zaman ona ulaşılamayan bir konumda konumlandırır (Andrew, 2010: 233). Dünyadaki gerçekliğin sorgulanması gibidir. Onu sorgular, bazen bulduğumuzu zanneder fakat ulaşıldığına düşünüldüğünde hala uzakta olunduğunun farkına varırız. Teknik yönden gerçekçiliğe baktığımız zaman, Bazin için sinemadaki gerçekçilik montajın olmadığı ve içsel olarak gerçekçi olması nedeniyle uzun planlarda, hammaddenin olgunlaşmamasında, sanatçının gerçekçiliğe bağlı kalması yolunda kendini dizginlemesinde ve eserin saf ile yalın şekilde seyirciyle bir araya gelmesidir (Andrew, 2010: 267). Buradaki uzun çekim ve onunla birlikte alan derinliği sinemanın gerçekliği konusunda belirleyici olmakla birlikte, fotoğrafla olan kimyasal ilişkisini de hesap ederek 
algısal gerçekliğine ve niteliğine işaret etmektedir. Gerçekçi olmayan sinema bir oyuncak gibi kullanılan ilginç, heyecan verici ve eğlenceli olabilir fakat bu bir oyalanmadan veya kendi niteliğinden uzaklaşmasıyla sonuçlanacak bilimsel bir enstrüman gibidir (Andrew, 2010: 197). Gerçekçilik, kuramcılar ve eleştirmenlerden çok 1920 lerde Sovyetler Birliği'nde Dziga Vertov, 1930'larda Fransa'da Jean Vigo ve İngiltere'de John Grierson, 1940'larda İtalya'da Roberto Rossellini, Cesare Zavattini ve Yeni Gerçekçiler gibi yönetmenlerin ilgisini çekerek, dışavurumculuğa karşı gerçekçi konumda yer alırlar ve bir konumlandırma arayışına girerler (Monaco, 2005: 377). Kracauer, sinemayı fotoğraf bakış açısıyla konumlandırır. Bu nedenle de hem fotoğraf hem de sinema gerçekliğin üretiminde konumlandırılabilecekleri için gerçekçiliği ön plana almaları gereklidir. Gerçekliği kaydedip onu göstermek konusunda sinema eşsiz bir yeteneğe sahiptir (Kracauer, 2015). İçerik, biçimden önemlidir ve önce gelir. Kracauer için, film bir amaca hizmet etmelidir ve saf bir estetik obje gibi yalnızca kendisi için varlık gösteremez (Monaco, 2005: 378). Sinema, etrafındaki dünyayla var olur ve gerçeklikten yola çıktığı için dönüp dolaşıp geleceği yer yine gerçekliktir. Gerçek olaylardan esinlenen film, esinlendiği olayın sonuçlarını göz ardı ederek yeni sonuçları kabul ettirmesi simülasyondur. Bunu da hem ele aldığı olaydan esinlenerek hem de gerçeği Sayfa | 1169 yok sayarak sağlamaktadır. Bunu yapabilmesi adına kullandığı araç ise gerçeğin yok sayıldığı görüntüler olarak nitelendirilebilen simulakrlardır. Simulakrları da üç grupta toplayabiliriz. İdeal doğanın bir benzerinin oluşturulmasını amaçlayan imgeleme, taklit ve kopyalama üzerine kurulu doğal simülakrlar; evrensel düzeyde insana inanmayı amaçlayan, nereden başlayıp nerede bittiği belli olmayan ve geniş bir yayılma hedefinde olan enerjiyi özgürleştirme peşindeki simülakrlar; bilgi ile modelden oluşan, hipergerçeklik ve mutlak denetim hedefindeki simülasyon simülakrlar olarak ele alınmaktadırlar (Baudrillard, 2011: 161). Gerçek görüntüler yerine bir amaç adına daha memnun edici sonuçlar elde edilmek için üretilmektedirler. Hipergerçekliğin başladığı bu noktada ve simülasyonlar vasıtasıyla gerçeklik değişir. Gerçeklik, komutlara, kodlara, hücrelere ve makinelere bağlıdır. Simülasyon ilkesinin belirlediği günümüz dünyasındaysa gerçek, modelin kopyasından başka bir şey olamamaktadır (Baudrillard, 2011: 164). Sinema bu nedenle hassas bir noktadadır ve bir köprü görevi görebilir. Gerçekliğe dair izlenimleri hem destekleyebilir hem de köstekleyebilir (Monaco, 2005: 378). Sinema, bu nedenle bir sanattır. Sizi hem olduğunuz yerde tutabilir hem de aynı anda başka mecralara yelken açtırabilir. Unutulmamalıdır ki gerçeklikle bağın azaldığı bir durumda oyun ve eğlence dünyasında sanal 
bir duyumsamaya yöneldiğimizde sanat güçlenmez, aksine varlık sebebini kaybeder (Andrew, 2010: 196).

\section{SİNEMA VE KORKU}

Belgesel, aksiyon, bilimkurgu, fantastik, komedi, müzikal, suç, western gibi sinema türleri bulunduğu gibi korku da bunların arasında dikkat çeken sinema türlerinden bir tanesidir. Korkmak, insanın başlangıcından itibaren benliğinde olan bir duygudur. Karanlık Çağ'da mağara zamanlarından başlayan, insanın etrafını anlamlandırması ve güvende hissetme süreci varlığını günümüzde de etkisini gösterir. İlk zamanlardaki insanlar için, hayatını sürdürebilmek, avlanmak ve barınmak bilinmezlik içerisinde devam eder. Balta girmemiş ormanlardaki bilinmezlik, kaybolma ve avlanırken av olabilme gibi bilinmezliğin getirdiği durumlar, insanın daima dikkatli olmasına sebebiyet verir. Mağaradaki yaşamı barınma intiyacından dolayı görebileceğimiz gibi güvende hissetme arzusunu da vurgulamaktadır. Bu sayede dikkat kesileceği tek bir yön vardır ve imkânlar doğrultusunda da yaşadığı bölgeyi güvenli hale getirmeye çalışır. Gündüz göz görür, ayrıntıları seçebilir. Gecenin getirdiği karanlık ise bilinmezliğin getirdiği korkuyu da tetikler. Vahşi hayvanlara karşı tetikte olunması sonucu, insan adeta diken üstündedir.

Günümüzde, temel ihtiyaçlardan sayılabilecek barınma ve güvende hissetme durumu belki de eski çağlardan günümüze aktarılarak günümüz insanına ulaşmaktadır. Bununla birlikte karanlık ve bilinmezliğin getirdiği tehditkârlık da yine bu çağlardan gelerek bugünün insanını da etkilemektedir. İnsan sinemaya gülmek, eğlenmek, heyecanlanmak, ağlamak ve bununla birlikte korkmak için de gider. Sinema bir duygu aktarım aracıdır. Bunların arasındaki korku ise insanoğlu için her ne kadar istenmese de cazip halde varlığını sürdürür. Bilinmeyen olan, bilinmeze merak, araştırma içgüdüsü ve karanlığın vadettikleri insanı bir nevi baştan çıkarır. Kendini onu araştırmaktan, ona bakmaktan ve sinemadaysa da perdeyi izlemekten alıkoyamaz. Korku filmlerinin bir ülkenin tarihiyle ya da coğrafyasıyla bağı bulunmaz ve her ülke sineması kendi korku filmlerini yaparak birbirlerini etkilerler (Abisel, 1995: 117). Ülke sinemalarının yaptığı korku filmleri, kendi hikâye ve motiflerinden etkilenerek meydana gelir. İzleyici, benliğini inşa ederken, bulunduğu ülkeden, coğrafyadan, masallardan ve geleneklerden etkilenmemesi düşünülemez. Kracauer, korku sinemasını toplumsal ve siyasal ortamla ilişkilerini ilk kez kuran ve sessiz Alman sinemasını incelediğinde bu dönemin bazı filmlerini Nazizm'in ön biçimlenişleri olarak ifade eder (Abisel, 1995: 120). Korkuyu tanımlayabilmek için psikanaliz bir yol göstericidir. Korku filmleri açıkça ya 
da yan anlamlarla doğrudan psikanalitik bazı kavramlara ve imgelere göndermede bulunmaktadır (Carroll, 2004: 257). Suspiria (1977), Şey (The Thing, 1982), Blair Cadısı (The Blair Witch Project, 1999), Korku Seansı (The Conjuring, 2013) gibi korku filmlerine baktığımız zaman, ışığın az olduğu karanlık yerlerin, tekinsiz ve terkedilmiş mekânların, insanların az veya hiç olmadığı ortamların, ne olduğu kestirilemeyen ve bilinmeyen nesnelerin, tanım getirilemeyen varlıklı sahneler; filmin genelini ve altyapısını oluşturmaktadır. Filmin hikâyesine yardımcı birer öğedir. Başlı başlarına birer anlatım unsurları ve bazen filmin çıkış noktalarıdırlar. Korku, gerçek korku ve nevrotik korku şeklinde ikiye ayrılarak incelenebilir (Freud, 1993: 227). Gerçek korku, dıştan gelen tehlikeye karşı oluşabilecek zarara tepkidir. Bu tehlike karşısında insan, durumu değerlendirip kendini bundan savunma adına önlem almasıdır. Kendini koruma adına, kaçmanın, savunmanın ya da karşı saldırıya geçmenin kararını verir. Korku, bireyi hayatta tutmak ve bütünlüğünü korumak adına önemli bir görev üstlenir ( $A$. Çağlıyan, 2020: 544). Nevrotik korku, gerçekte olmayan ama bilinçaltının harekete geçmesiyle benliğinde oluşan bir tehlike varmışçasına gerçekte de kendini tehlike içerisinde kabul etmesidir (Freud, 1993: 242). Bastırılmış korkuların kaynağı olan duygu ve bilinçaltının gün yüzüne çıkmasıdır. İnsan için ölüm, bir bilinmezliktir. Onu konumlandıramaz ve bu nedenle onu daima Sayfa | 1171 öteler. Freud, bireydeki ölüm düşüncesinden yola çıkarak onun tekinsiz bir duygu olduğunu belirterek onu bastırır ve bu süreçle akılda yabancılaştırılmaktadır (A. Çağlıyan, 2020: 545). Bilinmezlik insanın yüzleşmek istemediği bir durumdur. Bu durumla karşılaştığında, ona yakınlaştığında ya da içinde olduğunda korku süreci başlayarak gün yüzüne çıkar. Korku sineması da, bu duyguları ortaya çıkartıp onları bir nevi manipüle ederek izleyicisini korkutmayı amaçlar. Sinemada gösterilen ne olursa olsun, gösterilen sadece bir araçken; korkuyu aktif eden onu ortaya çıkartıp görünür kılan izleyicidir. Korku sineması, temel korku ve kaygılara yaslanarak, dünyanın neresinde gösteriliyor olsa da izleyicisini bulabilmektedir (Abisel, 1995: 117). Bunlarla birlikte, izleyici sinemada kendisinin kandırımasını arzular. Bu da korku filminin gerçek olma düşüncesiyle gerçekliğin nasıl kırılabileceğini göstermektedir. Geçmişten günümüze ulaşan hikâyelerin, kulaktan kulağa yayılan şehir efsanelerinin insanlar üzerindeki etkisi düşünüldüğünde, gerçek olma olasılığının bir korku hikâyesinin gücünü arttırabilmektedir (Kibaroğlu, 2019: 132). Gerçekliğe tutunmaya çalışan korku sineması, bu sayede izleyicisi üzerinde inandırıcı olarak hâkimiyet kurmak ister. Korku öğelerini içermesi bakımından ilk film olarak George Melies'in yönettiği Le Manoir du diable (Şeytanın İni, 1896) görülmektedir (Şimşek, 2012: 56). Sinemanın ilk 
dönemlerinde yer alan filmlerde korku ve gerçeklik toplumdaki olay ve hikâyelerden etkilenerek şeytan, hayaletler ve canavarlar öğeleri bu zamanlarda yer bulmaktadırlar. Ekonomik ve sosyal sıkıntılarla beraber II. Dünya Savaşı dönemi ve sonrasının getirdiği zorluklar bilimle dinin çatışması, vampir, yaratık imgelerinin görünür olmasına yol açar. 50'li yıllarla birlikte bilimkurgu-korku türünün doğuşu, kıyamet filmlerinin ortaya çıkarak yükselmesi; 70’li yıllarda masumiyete dönüş, şeytan çıkarma, antiİsa; 80 'lerle birlikte doğaüstü korkular, makinalara karşı insanlar, slasher ve oryantalist öğeler; sonrasındaki yıllarda slasher tarzı filmlerin artışı ve tekrar çevrimleri takip eder (Şimşek, 2012: 58). Sinemada kendilerine yer bulan bu öğelerin her biri hayatın ve gerçekliğin beyaz perdede yansımasıdır. Kameraların küçülmesi ve ulaşılabilir olması 2000'li yıllarda buluntu film örneklerinin artışına neden olur. Belgesel sinema öğelerinin kullanılarak sunulan içeriğin gerçekliğinin arttırılması amaçlanır. Belgesel formatıyla oluşturulan bu filmler, gerçeklere -yaşanan bir olaya- dayandığı iddiasıyla izleyicisine sunulur. Tekrar çevrilen filmler, başka ülke motiflerinin dâhil edilmesi ve doğaüstü olaylar tekrar bu dönemde ön plana çıkan bir başka öğelerdir. Bir sonraki bölümde incelenecek olan The Forest - 360 Experience'ın arka planda Japon kültürüne ait korku öğesi içermesi de bu noktada bir örnek teşkil edebilmektedir. Korku sineması toplumdaki Sayfa| 1172 değişimlerin, yeni akımların, ekonomik krizlerin, savaşların ve politikanın yol açtığı kaygı, gerilim ve korkuların kendine çıkış yolu bulduğu yer olarak tanımlanabilir (Ryan ve Kellner, 1997: 265). İnsan sıkıntılarından kurtulmak ister. Daha önce de bahsedildiği gibi sinema, insanın dertlerini bir süreliğine de olsa unutmasında, eğlenceli vakit geçirmesinde rol üstlenir. İzleyici bu etkinlik sırasında, şüpheciliğini ve gerçekliği bir kenara bırakabilir. Bu noktada Aristoteles'in Poetica adlı eserinde geçen katarsis terimden bahsetmek gerekir. Trajedinin seyirci üzerindeki etkisi ve kendi başına geliyormuşçasına gerilim, korku ve acıyla duyguları hissederek arınmasıdır. Bastırılan her türlü istek, arzu, gereksinim ve tepkinin, korku filmlerinin sağladığı özdeşleşmeler yoluyla tehlikesiz bir şekilde boşaltılabileceği iddia edilmektedir (Abisel, 1995: 120). Korku filminde de izleyici, içinde oldukları filmde bir çeşit nevrotik korku tesirinde ne kadar korkarsa korksunlar, bunun kurmaca olduğunu bilerek filmin biteceğinin farkında olma haliyle rahatlarlar. Bu sayede de kurmaca da olsa korkuyla yüzleşip bu histen kurtulmanın hazzını duyarlar. Filmdeki korku öznesinin son bulması ya da cezalandırılmasıyla izleyici kendi hayatındaki dertlerden bir süreliğine kurtularak veya bir süreliğine kurtulmanın gerginliğini üzerinden atar (A. Çağlıyan, 2020: 548). Gelinen son nokta, diğer türler gibi korku sineması 
da insan içindir ve onun istekleri doğrultusunda şekillenip görevini yerine getirir.

\section{THE CONJURING 2: VR EXPERIENCE VE THE FOREST - 360 EXPERIENCE ÇÖZÜMLEMELERİ}

\subsection{The Conjuring 2: VR Experience}

The Conjuring (Korku Seansı, 2013) filminin devamı olan The Conjuring 2 (Korku Seansı 2) filmi James Wan yönetmenliğinde 2016 yılında vizyona girer. Filmin gösterim tarihinden önce, yine 2016 yılında, filmin konusu dâhilinde 3 dakika 8 saniyelik bir VR filmi de dağıtımcı firma olan Warner Bros. Pictures tarafından yayınlanır. Yıl bazlı düşünüldüğünde bunun pazarlama açısından yapıldığı düşünülecek olsa da filmin konusuyla paralel böyle bir filmin yapımı, VR teknolojisinin yaygınlığının o yıllardan itibaren artmakta olduğunun işaretidir. VR filminin de film yapım şemasına sahip olması, onun sadece reklam amaçlı değil bir film olarak da bu alanda değerlendirilmesine olanak sağlar.

Film, doğaüstü olayları inceleyip çözmeye çalışan Ed ve Lorraine Warren çiftinin etrafında geçmektedir. Çift, Londra'nın Enfield bölgesindeki bir olayı incelemek ve yardım edebilmek için harekete geçerler. Tek başına dört çocuğunu büyütmeye çalışan Peggy Hodson, çocuklarıyla birlikte büyük Sayfa | 1173 bir eve taşınırlar. Çocuklar, geceleri hareket eden eşyalardan bahsetmeye başlasalar da; anneleri durumu ciddiye almaz. Çocuklardan birine dadanan bu tanımlanamayan olaylara dur demek artık çiftin elindedir.

The Conjuring 2: VR Experience, öncelikle bazı uyarılarla başlamaktadır. Kulaklıkların takılması ve ışıkların söndürülmesi istenir (bkz. Resim 1). Bu gerçekliği arttırmak ve izleyicinin şüpheciliğini bir kenara bırakması için onu hazırlamaktadır. Bunların arkasından VR başlığıyla birlikte döner bir sandalyede oturulması tavsiye edilir. Bu sayede film sırasında, daha rahat etrafa bakabilme ve yönü çevirebilme olanaklarından söz edilebilmektedir. Bunların arkasından filmin yönetmeni James Wan (bkz. Resim 2), evin önünde izleyeni karşılayarak selamlar ve eğlence dilemektedir. 


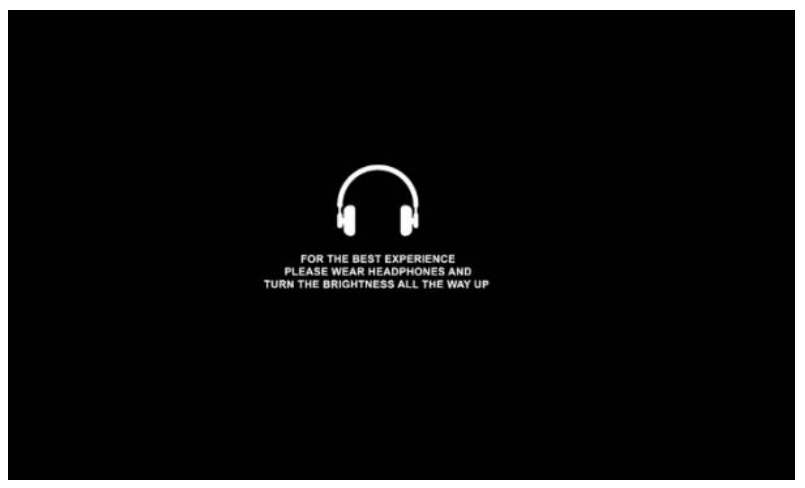

Resim 1: "The Conjuring 2: VR Experience" filminden kare

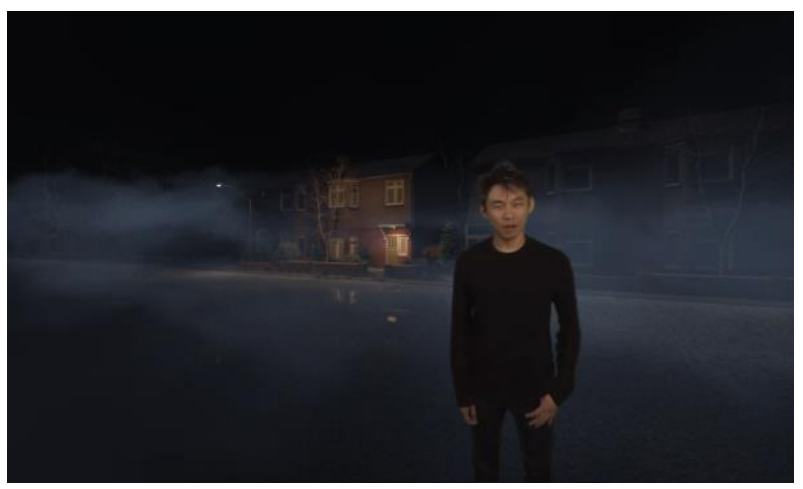

Resim 2: "The Conjuring 2: VR Experience" filminden kare

Film, evin oturma odasında başlamaktadır. Korku ve gerilim Sayfa| 1174 filmlerinden alışagelen çizgide etraf karanlıktır. Kısa süre içerisinde önce televizyon arkasında da lambader kendiliğinden açılır (bkz. Resim 3). Arkasından birkaç ışığın daha yandığı görülmektedir. Bazı konuşmalar işitilir ve sesin sahibi yaşlı bir adam izleyenin karşısında belirir (bkz. Resim 4). Cildi soluktur, gözlerinin rengi kırmızıya yakındır. Burasının kendi evi olduğunu söyler ve geldiği gibi kaybolur.

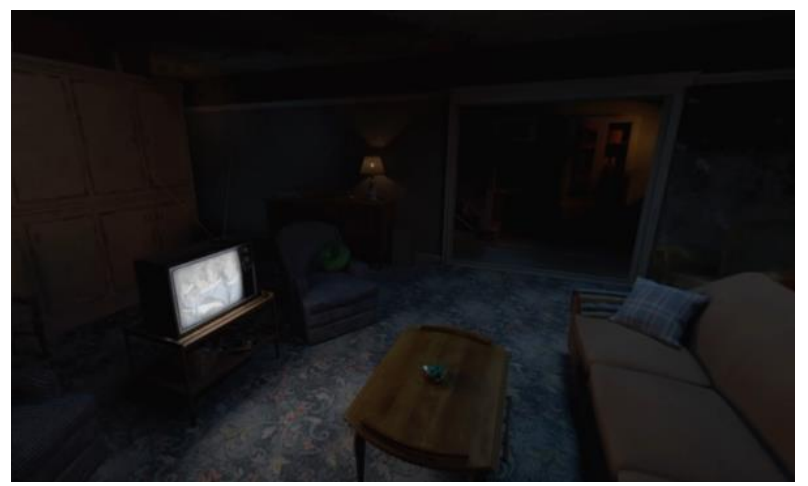

Resim 3: "The Conjuring 2: VR Experience" filminden kare 


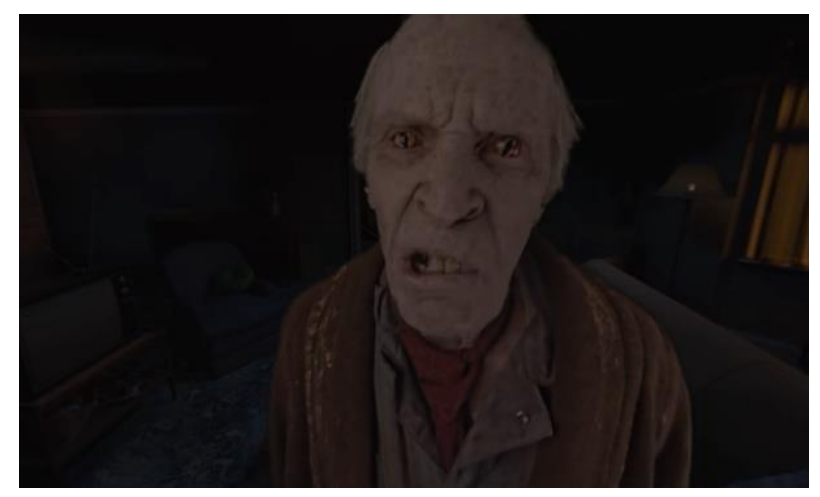

Resim 4: "The Conjuring 2: VR Experience" filminden kare

Bu kısımdaki karşıtlıklar; eski-yeni, karanlık-aydınlık, yaşlı-genç, ölüdiridir. Göstergelerin çözümlenmesi olarak ise televizyonun aniden açılması gösteren iken, gösterge olarak nesnedir ve bilinmezliğe hazırlık, korku film öğelerinden olan anidenlik ve olayların olağan olmayacağının işareti gösterilendir. Yaşlı adam gösteren, insan faktörü olarak göstergedir. Hoşnutsuzluğu, cilt ve göz renklerinden onun canlı olmadığı ve birden kaybolması sonu bunu vurgulaması da gösterilendir.

Bu noktadan sonra, izleyen oturma odasından kamera hareketiyle yükseltilerek ve bir başka odaya aktarılır. Yeni oda da karanlıktır. Odada iki yatak, posterler ve çalışma masasının bulunmasından dolayı burasının Sayfa| 1175 çocuk odası olduğu çıkarımı yapılabilmektedir. Odada bulunulan ilk anda, dolap kapısı biraz açılıp kapanır (bkz. Resim 5). Arkasından da masadan kitaplar düşer. Korku filmlerinden bilinmezlik öğesi, illa ki bir yaratık, tanımlanamayan bir varlıkla gösterilmez. Aniden hareket eden nesneler, olağan görüntüsüne rağmen konumlanışı bakımından aykırı durumlarda izleyen her an tetikte tutulmaktadır.

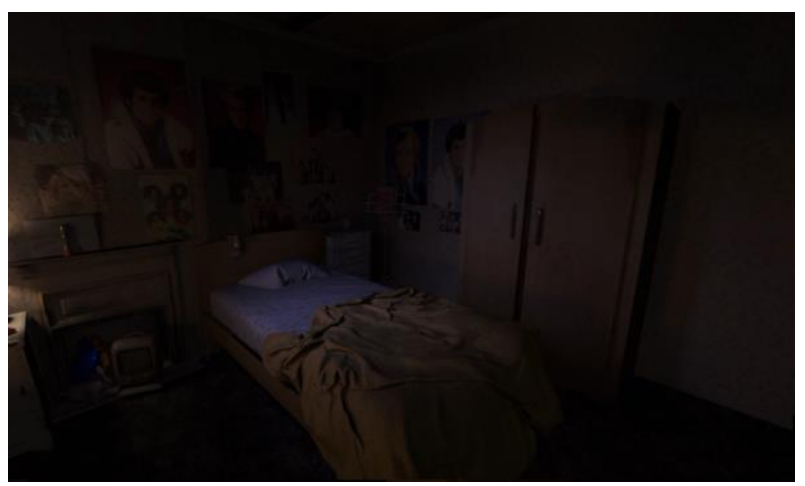

Resim 5: "The Conjuring 2: VR Experience" filminden kare

Genç-yaşlı, düzenli-dağınık, aydınlık-karanlık bu bölümdeki karşıtlıklardır. Dolap gösteren, gösterge ise nesnedir ve dolap kapısının açılıp kapanması, tekinsizlik ve bunun nedeninin bilinmemesi üzerinden 
doğaüstü olayın varlığı da gösterilen şeklinde göstergelerin çözümlenmesi yapılmaktadır.

Aynı odada ışıklar söner ve pencere kısmında görülen kırmızı ışık, soluk mavi tona dönüşür. Sarı renkte bir ışık odada döner ve sonrasında odanın bir başka versiyonuna geçilir. Eşyalar ve yatak ters düz olur. Duvarlarda posterler yerine asılı şekilde haçlar ve rahibe kıyafetleri içerisinde birinin portresi asılıdır. Odanın bir köşesinde tabut vardır. Pencere kısmının karanlığından rahibe kıyafetleri içerisinde olduğu anlaşılabilen bir gölge belirir ve portreye doğru hareket etmektedir (bkz. Resim 6). Bu sırada duvara asılı duran haçlar hareket etmeye ve ters dönmeye başlar. Gölge, portreyle aynı hizaya gelir ve portreyi izleyene doğru fırlatır. Filmin başındaki yaşlı adamdan sonraki bir başka izleyenle etkileşime geçilen sahnedir. Filmin başında kuşkuculuğun bir kenara bırakılmasının istenmesini ve gerçeklik olarak sanal gerçekliğin ön plana alınmasının istenmesini de hesaba katarak, izleyenin korku duygularıyla etkileşim sağlanmaktadır. İzleyen sadece bir izleyici değildir, film onu aktif hale getirir. Kendisi de filmin öznesidir. İzleyen, film izlediğini unutarak, portrenin kendisine çarpacağını düşünür ve irkilir.

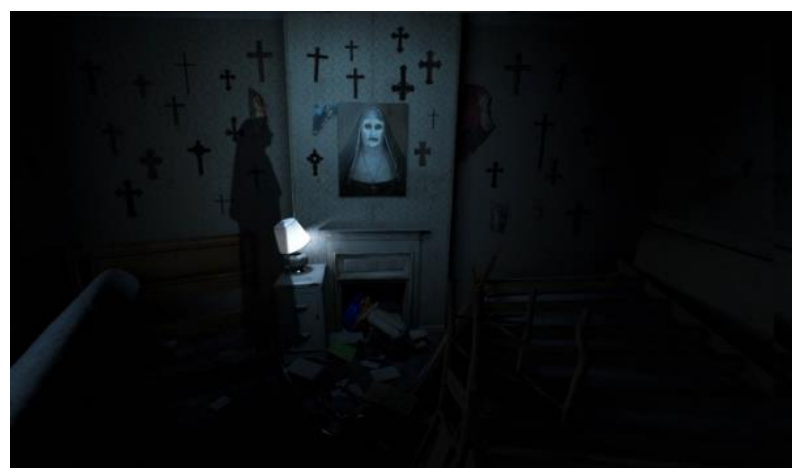

Sayfa | 1176

Resim 6: "The Conjuring 2: VR Experience" filminden kare

Ölü-diri, karanlık-aydınlık, aktif-pasif, gerçeklik-sanal gerçeklik bu kısımdaki karşıtlıklardır. Göstergelerin çözümlenmesi olarak ise, portrenin fırlatılması gösteren, gösterge ise nesnedir ve izleyiciyi de filmin öznesi kılınması, gerçeklik ve sanal gerçekliğin arasındaki sınırla oynanması gösterilendir.

Odanın kapısı kendiliğinden açılır ve hole geçilir. Hole çıktıktan sonra sola doğru hareket edilir ve holün sonunda ayakta dikilen kumaşlarla sarılı bir varlık bulunmaktadır (bkz. Resim 7). Bu sırada kapı çalma sesi duyulur. Holün diğer yönünde beyaz kısımları seçilebilen rahibe yavaşça izleyene doğru yaklaşmaktadır (bkz. Resim 8). Birden kaybolur ve oyuncak itfaiye aracı ışıkları da yanar bir şekilde hareket eder. Bu sırada hole çıkmadan 
önce bulunulan odanın kapısı kendiliğinden kapanır. Oyuncak itfaiye aracı hol boyunca ilerleyerek kumaşlarla sarılı nesnenin dibinde durur. Kısa zaman sonra ayakta dikilen varlık, yere doğru içi boşmuş gibi süzülerek, sadece kumaş parçaları geride kalır. Ekran kararır ve korku film öğelerinin klasik kullanımlarından olan birdenbire kavramı dâhilinde, rahibe ellerini uzatmış bir şekilde izleyenin dibinde biter (bkz. Resim 9). Film son bulur.

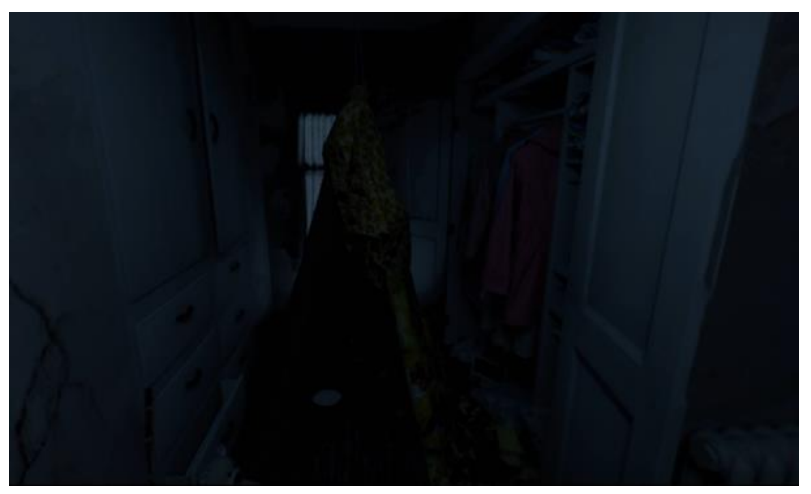

Resim 7: "The Conjuring 2: VR Experience" filminden kare

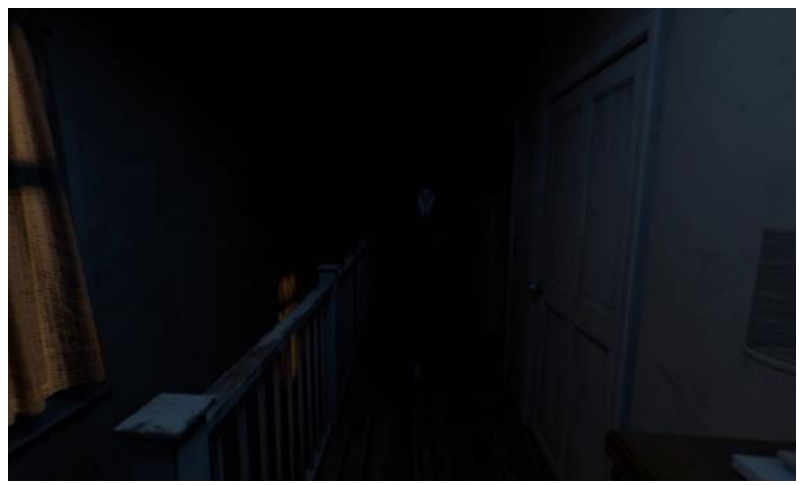

Resim 8: "The Conjuring 2: VR Experience" filminden kare

Bu kısımdaki karşıtlıklar, aydınlık-karanlık, ölü-diri, gerçeklikyapaylıktır. Ayakta dikili vaziyetteki kumaşlarla sarılı varlık gösteren, nesne ise göstergedir ve bilinmezlik, tanımlayamamak ve bilinmezden korkuyla karışık merak duygusunun tetiklenmesi de gösterilendir. Rahibe gösterenken, insan faktörü olarak göstergedir. İnsan olarak tanımlansa da rahibenin ses çıkarmaması, güven vermemesi, aniden yok olup aniden belirebilmesi de onun insan yerine başka bir varlık ve kötü amaçlara sahip olduğu gösterilen olarak göstergelerin çözümlenmesi yapılabilmektedir. 


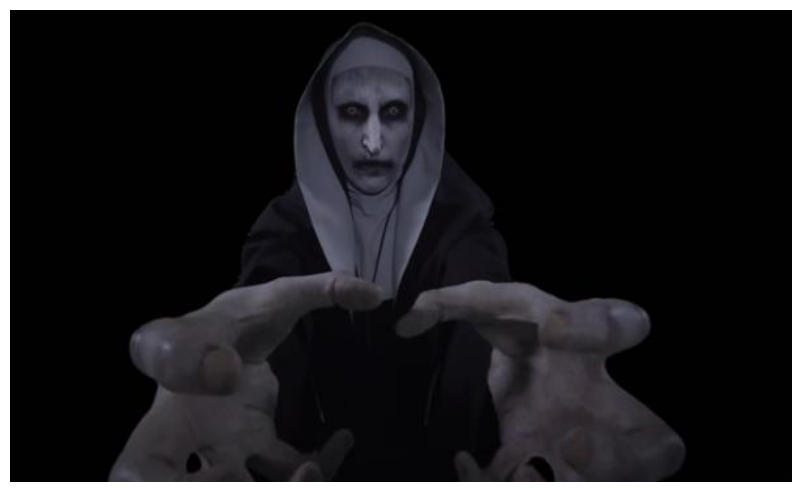

Resim 9: "The Conjuring 2: VR Experience" filminden kare

\subsection{The Forest - 360 Experience}

The Forest (Orman) filmi Ben Ketai, Nick Antosca ve Sarah Cornwell senaryosunu yazdığı ve Jason Zada yönetmenliğinde 2016 yılında vizyona girer. Filmin gösterim tarihinden önce, aynı yıl içerisinde filmin mekânlarından olan çadırda geçen 1 dakika 20 saniyelik VR filmi de filmin dağıtımc firmalarından bir tanesi olan Sony Pictures tarafından yayınlanır. Çalışma kapsamında incelenen diğer film gibi, bu filmin yapım yılı gözetildiğinde VR teknolojisine ve filmlerine ilginin arttığı gözlenmektedir. VR filmini sadece filmin pazarlanması için yapılan bir öğe olarak değil; sinema unsurlarını gözeterek film nesnesi dâhilinde ele alınıp Sayfa|1178 değerlendirilmesi yapılabilmektedir.

Filmin konusu, Sara gizemli bir şekilde ortadan kaybolan ikizini aramak için onun son görüldüğü yer olan Japonya'da bir ormana gider. Burada yerel halk tarafından tembihlenmesine rağmen ormanın gitmemesi gereken yerine doğru sapar. Ormanın derinliklerinde sarı bir çadır keşfederler. Sara, ikiz kardeşine ait olan çadırı tanır. Geceyi çadırda geçirmeye karar verir ve doğaüstü olaylarla yüzleşmek zorunda kalır.

The Forest - 360 Experience, incelenen diğer film gibi bazı uyarılarla başlamaktadır. Kulaklık takılmasını ve telefonun ters yatırılarak izlenmesini ya da görüntüleyici setlerinden kullanılmasını iyi bir izleme deneyimi için önermektedir (bkz. Resim 10). Bu uyarılar, sadece izlenme deneyimini iyileştirmek için değil, filmin gerçekliğini ve izleyenine etki edebilmesini sağlayabilmek için de kullanılmaktadır. Film, sarı bir çadırın içerisinde başlar. Bu çadır, filmin konusunda da geçen çadır olduğu bilinmektedir. Çadırda, İngilizce ve Japonca yazılı kapağı olan birkaç kitap, örtüler, uyku tulumu, viewmaster, bez bebek, ilaç kutuları ve sırt çantası bulunmaktadır. Gece vaktidir ve etraf karanlıktır. Dışarıda ateşten geldiği tahmin edilebilen ışık kaynağı aydınlatıcı görev görmektedir (bkz. Resim 11). 


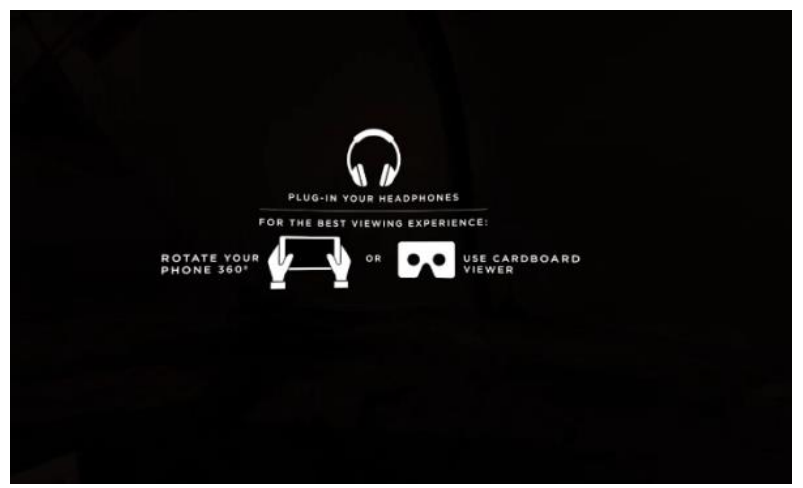

Resim 10: "The Forest - 360 Experience" filminden kare

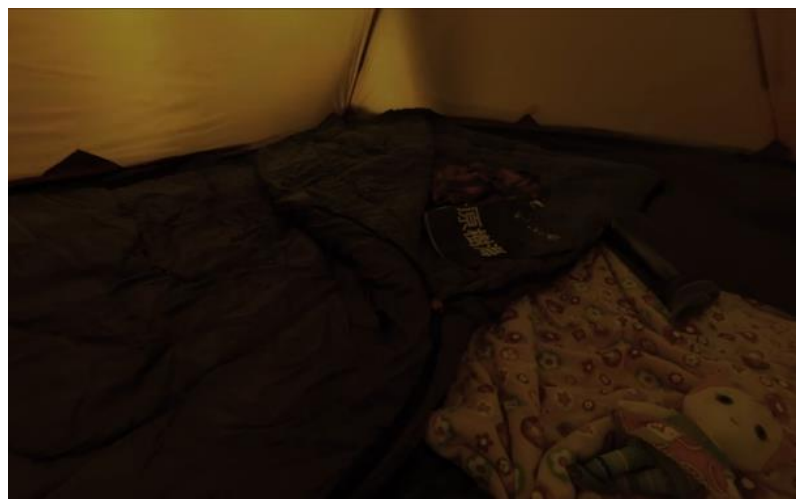

Resim 11: "The Forest - 360 Experience" filminden kare

Bu kısımdaki karşıtlıklar; karanlık-aydınlık, sıcak-soğuk, gerçeklikyapaylıktır. Göstergelerin çözümlenmesi olarak ise çadırın içi gösteren, gösterge olarak nesne iken; ortam hakkında fikir vermesi, izleyenini filme hazırlaması ve izleyenin gerçekliğiyle oynayarak onu filmin içerisine dâhil etmesi de gösterilendir.

$\mathrm{Bu}$ andan itibaren izleyen, rahat ortamında değil, ormanın karanlığındaki çadırın içerisindedir. Bu esnada 'Sara" diye dışarıdan kadın sesi duyulmaktadır. Sesle de birlikte çadırın etrafında dolaşan üç tane insana benzeyen gölgeler görülür ve kaybolurlar (bkz. Resim 12). Nefes alışverişinin hızlandığı duyulur. İzleyenin kendi benliği bir köşeye bırakılır ve ona biçilen rol 'Sara" karakteridir. 


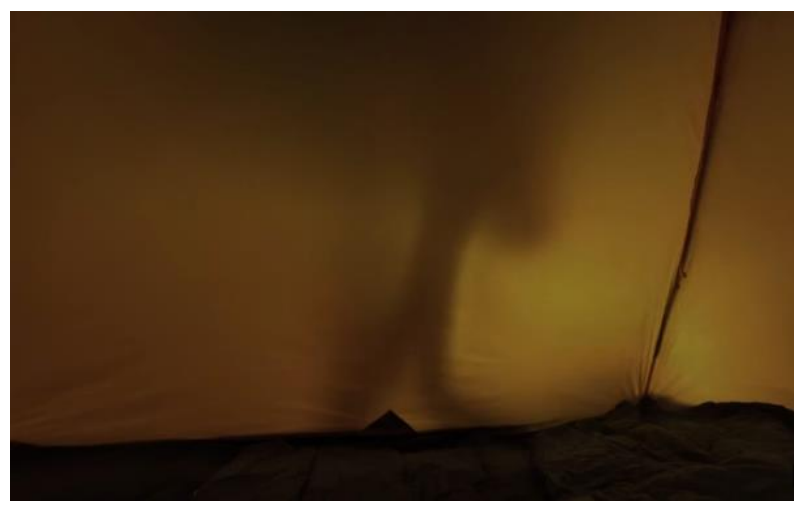

Resim 12: "The Forest - 360 Experience" filminden kare

Normal-tuhaf, aydınlık-karanlık, sakin-heyecanlı, dost-düşman bu bölümdeki karşıtıklardır. Çadııın üstüne düşen varlığın gölgesi gösteren, gösterge olarak nesnedir ve insan ya da başka bir varlık olduğunun bilinememesi, dost-düşman konumunun netleştirilmemesi de gösterilen olarak göstergelerin çözümlenmesi yapılabilir. Varlığın bilinmezliği, onun amacının muğlaklığı bir tehdit unsuru oluşturur. Bu nedenle de karakter ve onun konumlandırıldığı izleyen, kendini güvende hissedemeyerek, tetikte durmaya zorlanır.

Kadın sesinden "Sara" isminin işitilmesiyle tekrar gölgeler görülmektedir. Bu sefer içeriye girmek ister gibidirler ve çadıraSayfa| 1180 dokunmaktadırlar. Bu esnada ışık kaynağı azalır ve bir anda çadırın içerisinde iki yaratık belirip ve kaybolurlar (bkz. Resim 13). Çadırın fermuarının dıştan yavaşça açıldığı görülür. Önce bir kadın daha sonra ise erkek sesi tarafından "Sara" ismi tekrar duyulmaktadır. İçeriye, daha önce kısa süreliğine çadırın içerisine görülen yaratık girer ve hızlıca izleyene doğru hareket eder (bkz. Resim 14). Ekran kararak film biter.

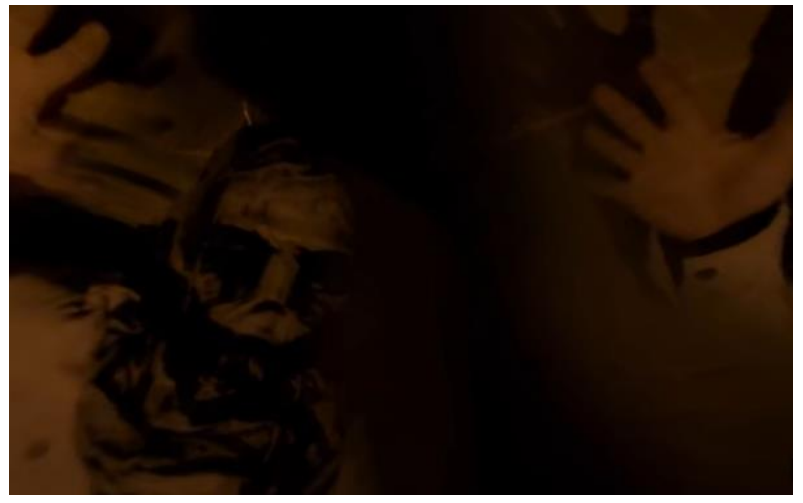

Resim 13: 'The Forest - 360 Experience" filminden kare 


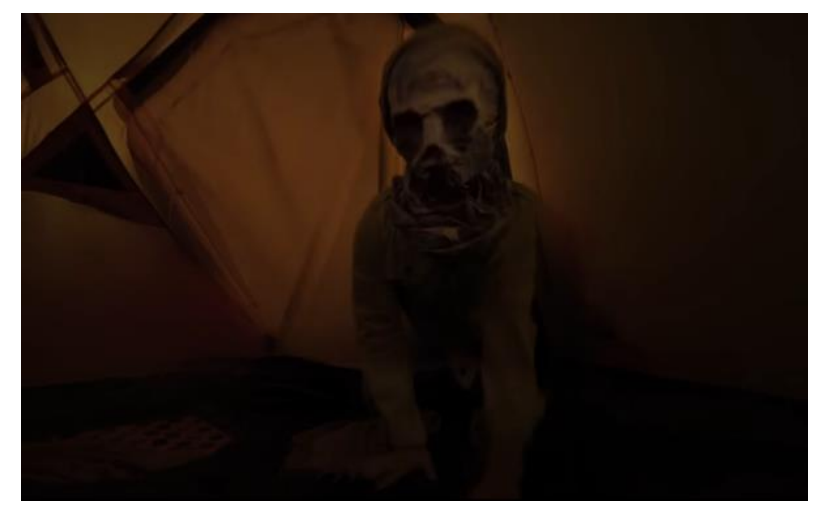

Resim 14: "The Forest - 360 Experience" filminden kare

Bu kısımdaki karşıtlıklar; yakınlık-uzaklık, tanınan-yabancı, normaltuhaf, aydınlık-karanlıktır. Göstergelerin çözümlenmesi olarak ise, çadırın içerisinde birden görülen yaratıklar gösteren, gösterge olarak ise nesnedir ve bilinmez bir varlık oluşları, istedikleri gibi yakın ya da uzak olabilmeleri sonucu oluşan tehdit unsuru gösterilendir. Çadırın fermuarını açarak içeri giren yaratık gösteren, gösterge ise nesne iken, çadırın fermuarının yavaşça açılması gerilimi arttırıc bir unsur ve yaratığın hızlıca içeri girerek tehdit oluşturması da gösterilendir. Ne yapacakları bilinmemektedir. Bu bilinmezlik de bir tehdit unsurudur ve tehlikede olma hissiyatı, insanın kendisini tehditlere karşı koruma içgüdüsüyle hareket etmesine yol açar. Çadırın Sayfa| 1181 içerisinde hızlıca girmeleri, yok olup birdenbire tekrar belirmeleri, izleyenin olabilecek en yakınına gelmeleri korku sinemasının öğelerinin kullanımlarına da birer örnek teşkil etmektedir. Çadırın fermuarının yavaşça açılması gerilimi arttırması sonucu izleyenler kendini gelebilecek tehlikelere hazırlarken, yaratıkların bu hareketleri de bu gerilimi en zirveye taşıma görevi üstlenmektedirler.

\section{SONUÇ}

Gerçekliği ne kadar tanımlamaya çalışsak da sanal gerçeklik kavramıyla birlikte her iki kavramın keskin sınırlarının belirsizleşmeye başladığı gözlemlenmektedir. Bunun nedeni olarak sanal gerçekliğin gerçek dünyaya benzer ya da tamamen farklı olabilen simüle edilmiş bir bilgisayar teknolojisinin gerçekliğe olan benzerliğidir. Yaratılan bu yeni gerçeklik, insanların güvenli ortamlarında bu gerçekliğini deneyimlemelerine ve hatta yaşamalarına olanak sağlamaktadır. Eğlence, eğitim, tasarım, turistik, mimari, kültür ve sanat alanlarında kullanılan bu teknolojinin görüldüğü üzere hemen hemen dışarıda bıraktığı bir alan yoktur. Teknoloji kapsamında yansıtılan gerçeklik algısının geliştirilmesi ve kullanıldığı alanlarda aktif olarak fayda sağlaması da gözlemlenmektedir. 
Sinemanın var olma süreci gibi, sanal gerçeklik de bugünkü haline gelebilmesi için belirli yollardan geçer. Bugün, standart sanal gerçeklik sistemleri, bir kullanıcının sanal bir ortamda fiziksel varlığını simüle eden gerçekçi görüntüler, sesler ve diğer duyu organlarını harekete geçirebilmek adına sanal gerçeklik araçlarını kullanırlar. Böylece kullanıcı, bu yeni dünyada etrafına bakabildiği, gezebildiği veya etkileşime girebileceği yeteneklere sahip olur. 1962 yılında bütün gereçlerin bir arada olduğu, adeta bir odanın içerisine girerek gerçekleştirilen ve bu alandaki ilk cihaz olarak kabul edilen devasa The Sensorama'yla süreç başlar. Giyilecek başlığın ağır olması nedeniyle tavana asılması gerekliliği ortaya çıkan ve bu nedenle "Demokles'in Kılıcı" adını alan cihazla; bu süreçlerden sonra günümüzde de yaygın olarak kullanılacak olan sanal gerçeklik başlıklarına doğru bir teknolojik bir süreç geçirilir. Sürecin geldiği yer itibariyle, devasa bir cihaz ya da geniş bir alan olmadan, yalın haliyle günümüz sanal gerçeklik gözlükleri son derece kullanılabilir ve ulaşılabilir konumdadırlar. Bu kolay ulaşılabilirlik de kendisinin sinemanın da içinde bulunduğu çeşitli alanlarda kullanılmasına yol açar.

Gerçeklik, insanın dünya üzerindeki varlığında kendisiyle beraber çevresini anlamlandırabilmesi, bunu bir konum içerine yerleştirebilmesi ve benliğini bunun üzerine temellendirebilmesi adına temel taş görevini Sayfa| 1182 üstlenmektedir. Bu temel taş nedeniyle de insanın gerçekliğe dair arayışı ve merakı devam eder. Teknolojik gelişmelerle birlikte hayatımıza giren sanal gerçeklik, artırımış gerçeklik, karma gerçeklik, genişletilmiş gerçeklik gibi yeni gerçeklikler üzerinden gerçeklik sadece dünyaya bağlı bir konumdan çıkar. Gerçeklik, düşünülebilen ve biçimlenebilenin tersine, gerçekte var olan ve varlığı anlamlandırmadan bağımsızdır. Bu nedenle gerçeklik tasarımsal ve imgelerden oluşan dünyada da kendi yerine sahiptir. Duyularımız tarafından gerçekten oradaymış hissinin deneyimlendiği sanal bir ortamda, çeşitli araçlarla etkileşim de sağlanmaktadır. İnsan, özündeki kendini ifade etme arzusuyla, bu ortamda da eserler üretmeye ya da bu ortama yönelik eserler meydana getirmeye başlar. Bu yeni gerçeklikte kendini var eden insan, bu ortamı sanatın ifadesi adına yeni araçlara dönüştürmektedir. Lumiere kardeşlerin, trenin gara girişi gösterimi sırasında izleyicilerin izlediklerini gerçek sanarak gösterimi sırasında kaçışmaları, sinema ve gerçekliğin ilk zamanlardan itibaren kesiştiklerini göstermektedir. İzleyici, günümüzde de dilediği herhangi bir izleme aracını kullanırken dahi bulunduğu andan koparak izlediğine dikkatini verir. Gerçek olaydan alınarak yansıtılan bir sahnenin, olayın kendisinden daha gerçekçi etki yapması; filmin iyi hazırlanmasıyla değil, onun gerçeklik etkisini gözler 
önüne seren niteliktedir. İzleyicinin belki de görmediği ve deneyimlemediği olaylara filmlerle birlikte ağlayarak, gülerek, heyecanlanarak ve korkarak erişir. Sinemadaki gerçeklik de insanın gerçeklik arayışı gibi devamlı sorguladığı, onu bulduğunu düşündüğü ve ulaşıldığını düşündüğünde uzakta olduğunu anladığı bir konumdadır. Sinema, etrafındaki dünyayla var olur ve gerçeklikten yola çıkması nedeniyle döneceği yer yine gerçekliktir.

Sinema türlerinden bir tanesi olan korku, insanın bilinmeze merak, araştırma içgüdüsü ve karanlığın vadettiklerinden hareketle sinemada da izleyicisini kendine çeker. Korku sineması, toplumdaki değişim, ekonomik sosyal olaylar ve kültürdeki olumsuz gerçekliği, kendi sinemasal araç ve öğeleriyle birleştirerek ele alır. Gerçeklik korku sinemasında, insanların az veya hiç olmadığı ortamların, ne olduğu kestirilemeyen ve bilinmeyen nesnelerin, tanım getirilemeyen varlıkların, doğaüstü korkuların, makinalara karşı insanların, dünyanın sonunun konu edildiği, gerçekliği arttırabilmek adına belgesel türündeki buluntu film tarzı öğelerle kendine yer bulur. Sinemada kendilerine yer bulan bu öğelerin her biri hayatın ve gerçekliğin beyaz perdede yansımasıdır. İzleyici, sinemada kendi gerçekliğini bırakarak yeni bir gerçekliğe kapılmak ister. Bu da korku filminin gerçek olma düşüncesiyle gerçekliğin nasıl kırılabileceğini göstermektedir. Bir korku hikâyesinin gerçek olabilme olasılığı, hikâyenin Sayfa | 1183 gücünü arttırarak izleyicisini etkilemektedir. Gerçekliğe tutunmaya çalışan korku sineması, bu sayede izleyicisi üzerinde inandırıcı olarak hâkimiyet kurmayı amaçlar.

Sanal gerçekliği, sinema özelinde ele alarak inceleyen bu çalışma kapsamında; sinemanın geldiği noktadan itibaren gerçekliği kendi öğeleriyle yansıtması da sanal gerçeklik teknolojisinin kullanımına benzetilebilir. Sinemanın bir illüzyon olduğunun altı çizilerek, sanal gerçeklik de bu kapıdan içeri girip izleyicisinden bakılmasını istediği noktaya yönlendirir. İzleyiciden şüpheciliğini bir kenara bırakarak içeri girmesini isteyen sanal gerçeklik, bunu kullanarak gerçeklik algısını da arttırmayı amaçlar. Korku filmleri özelinde incelenen sanal gerçeklik ve The Conjuring 2: VR Experience ile The Forest - 360 Experience örneklerine bakıldığında, örneklerin yıl itibariyle filmlerin pazarlanması olarak kullanılmaya başlanmasına rağmen kendi başlarına birer film öğelerinin taşıdıkları görülmektedir. Bu sayede yapılan film incelemelerinde korku sinema anlatılarından da yararlanıldığı planlarla birlikte gerçeklik kavramı birleştirilerek izleyenlerin gerçeklik kavramı bulanıklaştırılarak onları filmlere dâhil ederler. Göstergebilimle birlikte yapılan çözümlemelerde bu VR örneklerinin korku ve gerçeklik öğelerinin göstergeleri incelenerek 
ortaya konulmaktadır. Bu eksende ortaya konulan en belirgin öğelerden bir diğeri de, filmde rol alan, filmi yaşayan ve filmin öznesi artık izleyendir. İzleyicinin yönlendirmeleri, görüş tarafları ve olay örgüsüne göre imkân dâhilindeki tepkileri filmin devamlılığını sağlamaktadır. Filmi yöneten, yazan ve çeken bir ekip olmasına rağmen, anlatıcısı, onu hayata geçireni izleyendir ve bu tamamen onun sorumluluğundadır.

Sinema, her olaydan ve her ilerlemeden kendi payına düşeni alıp, kendisini değiştirmek ve geliştirmektedir. Fotoğraftan yola çıkarak, filmlerin renklendirilmesi, kurgu imkânları, animasyonlar, görsel efektler ve 3D gibi özellikler de bu gelişimin sonuçları arasındadır. Henüz yeni yeni tanışıyor olsalar da sanal gerçeklik ve onun getirdikleri de sinemanın içerisinde daha sık görülmeye ve yakın gelecekte sinemanın olağan bir parçası olarak algılanacağı çıkarımı yapılabilmektedir.

\section{KAYNAKÇA}

Abisel, N. (1995). Popüler Sinema ve Türler. İstanbul: Alan Yayıncılık.

Andrew, J. D. (2010). Büyük Sinema Kuramları. (Çev.). Zahit Atam. İstanbul: Doruk Yayımcılık.

Artaud, A. (1958). The Theatre and Its Double. (Çev.). Mary Caroline Richards. New York: Grove Weidenfeld.

Aydoğan, D. \& Kaplanoğlu, L. (2020). Toplum, Sanat ve Sanal Gerçeklik. Yeni Medya Elektronik Dergisi 4, 79-88.

A. Çağıyan, E. (2020). Korku Sinemasının Cazibesi Üzerine Felsefi ve Psikolojik Bir İnceleme. SineFilozofi 5(9), 540-550.

Barlow, J. P. (1990). Being in Nothingness. Wired. Erişim Adresi: https://www.wired.com/2015/04/virtual-reality-and-the-pioneers-of-

cyberspace/ Erişim Tarihi: 02.01.2020.

Barthes, R. (2005). Göstergebilimsel Serüven. (Çev.). Mehmet Rifat \& Sema Rifat. İstanbul: Yapı Kredi Yayınları.

Baudrillard, J. (2011). Simülakrlar ve Simülasyon. 6. Bs. (Çev.). O. Adanır. Ankara: Doğu Batı.

Bazin, A. (2011). Sinema Nedir? (Çev.). İbrahim Şener. İstanbul: Doruk Yayıncilık.

Buzjak, D. \& Kunica, Z. (2018). Towards Immersive Designing of Production Processes Using Virtual Reality Techniques. Interdisciplinary Description of Complex Systems (16)1, 110-123. 
Carroll, N. (2004), Psychoanalysis and the Horror Film. Horror Film and Psychoanalysis: Freud's Worst Nightmare. (Ed.). Steven Jay Schneider. S. 257-270, New York: Cambridge University Press.

Craig, A. \& Sherman, W. \& Will, J. (2009). Developing Virtual Reality Applications: Foundations of Effective Design. Amsterdam: Morgan Kaufmann Publishers.

Cruz-Neira, C. \& Sandin, D. J. \& Defanti, T. A. \& Kenyon, R. V. \& Hart, J. C. (1992). The Cave: Audio Visual Experience Automatic Virtual Environment. Communications of the Acm 35(6), 64-72.

Çınar, C. (2008). Sinema Estetiğinde Sinematografik Uzam ve Hareket Algısı. (Yüksek Lisans Tezi). YÖK Ulusal Tez Merkezi. 261839.

Eberwein, T. F. (1990). Yapısalcı Eleştiri: Christian Metz. Düşünceler. (Çev.). Zafer Özden. Yıl: 4, Sayı: 4.

Freud, S. (1993). Psikanalize Giriş-Genel Nevroz Öğretisi. (Çev.). Günsel Koptagel-İlal, İstanbul: Star Yaprak Yayıncılık.

Gownder, J. P. \& Voce, C. \& Mai, M. \& Lynch, D. (2016). Breakout Vendors: Virtual And Augmented Reality. Erişim Adresi: https://www.forrester.com/report/breakout+vendors+virtual+and+augme nted+reality/-/e-res134187, Erişim Tarihi: 28.12.2020.

Grau, O. (2003). Virtual Art: from Illusion to Immersion. Cambridge: Ma, Mit Press.

Guırand, P. (1994). Göstergebilim. (Çev.). Mehmet Yalçın. 2. Bs. Ankara: İmge Yayınları.

Jochum, K. 2021 Wird Das Jahr Der Virtual Reality. Inside It. Erişim Adresi: https://www.inside-it.ch/de/post/2021-wird-das-jahr-der-virtual-reality20201022, Erişim Tarihi: 02.12.2020.

Kracauer, S. (2015). Film Teorisi: Fiziksel Gerçekliğin Kurtuluşu. (Çev.). Özge Çelik. İstanbul: Metis Yayınları.

Kibaroğlu, B. (2019). Buluntu Filmler ve Korku Sinemasında Gerçeklik Yanılsaması. Sekans Sinema Kültürü Dergisi E11, 128-139.

Lotman, Y. M. (2012). Sinemada Göstergebilimi. (Çev.). Oğuz Özügül. 3. Bs. Ankara: Nirengi Kitap.

Metz, C. (1985a). Sinema Dil Dizgesinden Sinema Diline. (Der.). Büker, S. \& Onaran, O. Sinema Kuramları. Ankara: Dost Kitabevi.

Metz, C. (1985b). Sinematografik Dil Kavramı Üzerine. (Der.). Büker, S. \& Onaran, O. Sinema Kuramları. Ankara: Dost Kitabevi. 
Monaco, J. (2005). Bir Film Nasıl Okunur? Sinema Dili, Tarihi ve Kuramı. 6. Bs. (Çev.). Ertan Yılmaz. İstanbul: Oğlak Yayıncılık.

Nelson, T. (1982). Report on Siggraph '81. Creative Computing 8(3).

Özden, Z. (2014). Film Eleştirisi: Film Eleştirisinde Temel Yaklaşımlar ve Tür Filmi Eleştirisi. 3. Bs. Ankara: İmge Kitap Evi.

Psotka, J. (1995). Immersive Training Systems: Virtual Reality and Education and Training. Instructional Science 23(5), 405-431.

Regrebsubla, N. (2015). Determinants of Diffusion of Virtual Reality. (Diploma Tezi). Berlin Teknik Üniversitesi. Almanya: Grin Publishing.

Ryan, M. \& Kellner, D. (1997). Politik Kamera. İstanbul: Ayrıntı Yayınları.

Scales, T. (2018). The Reality from Virtual Reality. International Journal of the Academic Business World 12(2), 67-68.

Schnıpper, M. Seeing is Believing: The State of Virtual Reality. The Verge. Erişim Adresi: https://www.theverge.com/a/virtual-reality/intro, Erişim Tarihi: 02.12.2020.

Sutherland, I. E. (1968). A Head-Mounted Three Dimensional Display. Afips $68,757-764$.

Şimşek, G. (2012). Sinemada Korku ve Din: 2000 Sonrası Amerikan ve Türk Sayfa | 1186 Filmlerinde Cin Unsurunun Çözümlenmesi (Eleştirel Kuram ve Göstergebilimsel Metodoloji Çerçevesinde). (Doktora Tezi). YÖK Ulusal Tez Merkezi. 317418.

Türk, M. S. (2014). Medyanın Gerçeklik İnşası ve Gerçeklik Algısı. Düşünce Dünyasında Türkiz Siyaset ve Kültür Dergisi 5(28), 9-32.

Vardar, B. (2000). Sinema ve Televizyon Görüntüsünün Temel Öğeleri. İstanbul: Beta Basım Yayım.

Wu, H. K. \& Lee, S. W. Y. \& Chang, H. Y. \& Liang, J. C. (2013). Current Status, Opportunities and Challenges of Augmented Reality in Education. Computers \& Education 62, 41-49.

Zarka, O. M. \& Shah, J. S. (2016). Virtual Reality Cinema: A Study. International Journal of Research and Analytical Review 3(2), 62-66.

GENİŞLETİLMIŞ ÖZET: Sanal gerçeklik (Virtual Reality), gerçek dünyaya benzer ya da tamamen farklı olabilen simüle edilmiş bir bilgisayar teknolojisi deneyimidir. Sanal gerçeklik, altyapısını kullanan uygulamalar sayesinde turizmden eğlenceye, mimari yapıların tasarımından sanat turlarına kadar çeşitli alanlarda varlık göstermektedir. Son yıllardaki teknolojik gelişmeler ve VR ürünlerinin ev kullanıcısı için uygun hale gelmesi sanal gerçekliğe olan ilgiyi arttırmaktadır. Sinema ve VR arasındaki oluşan bu yeni ortaklık üzerine bilinmezlik 
ve çalışmaların az olması çalışmanın önem kısmını teşkil etmektedir. Bu çalışma sanal gerçekliğin sinemadaki izini sürerek, yapılan korku VR filmleri olan The Conjuring 2: VR Experience ve The Forest - 360 Experience'ı örneklem alıp her ikisini de çözümleme yoluna gitmeyi amaçlamaktadır. Göstergebilimden yararlanarak gerçekleştirilecek olan çözümlemede sinemadaki korkunun psikoloji yönünden de ele alınarak izleyici tarafındaki algılanmasına değinilecektir. Sinema bir dile sahiptir. Bu dilde şüphesiz ki görüntülerdir. Görüntülerin incelenebilmesi, gerçek ve yan anlamlarının görünür kılınması için de göstergebilim kullanılmaktadır. Çalışma kapsamında cevaplanmaya çalışılan bazı sorular çalışma öncesi belirlenmektedir. Bu sorular, VR teknolojisinin sinemayı ne yönde etkilediği; sinema ve VR ortaklığının gelişiminin nasıl bir süreçten geçtiği ve gerçeklik, gerçekçilik ve sinema ilişkisinden de hareketle filmlerde ne tür yansımalar oluşturduklarına cevaplar aranmaktadır. Çalışma için sanal gerçekliğin gelişimi, teknolojik altyapısının anlaşılması, sinemayla olan ilişkisi, sinemada korku ve gerçeklik, gerçekçilik ve sinema konularındaki yurtiçi ve yurtdışındaki kaynaklara ulaşılarak, çalışmada yararlanılmaktadır. Çalışmanın birinci bölümünde, sanal gerçeklik tanımlanarak açıklanmaktadır. Tarihsel gelişimine bu kısımda değinerek, gelişim süreciyle birlikte kullanım alanının genişlemesi ve sinemayla başlayan ilişkisi ele alınmaktadır. Gerçeklik, gerçekçilik ve sinema konusundaki çalışmalara dair literatürdeki görüşlere verilerek, çözümleme öncesinde kuramsal yaklaşımlar ve tartışmalar açıklanmaktadır. Ardından, örneklem filmlerinin korku türünde olması nedeniyle sinema ve korku ilişkisine de değinilerek çözümleme için altyapı Sayfa | 1187 oluşturulmaktadır. Çözümleme kısmına geçildiğinde ise önce filmler teknik bilgileriyle birlikte hikayelerine değinilmektedir. Yapımcı firmalar, örneklemlerin süreleri ve hikayeleri gibi detaylar örneklemlerin incelenmesinde ayrıntılar sunabilmektedir. Hikayelerin geçtiği mekanlara göre, kültürel ve sosyolojik öğeler daha dikkatli aranabilmektedir. Göstergelerin çözümlenmesi bakımından bütün ayrıntılar önem arz etmektedir. Örneklemler üzerinden toplanan göstergelerin çözümlenmesinde göstergebilimden yararlanılmaktadır. Görüntülerin seçilerek, Roland Barthes'in anlamlandırma ile Ferdinand de Saussure'ün gösterge anlayışları temel alınmakta ve göstergelerin ürettikleri anlamlar çözümlenmeye ve yorumlanmaya çalışılmaktadır. Sanal gerçekliği, sinema özelinde ele alarak incelenen bu çalışma kapsamında; sinemanın geldiği noktadan itibaren gerçekliği kendi öğeleriyle yansıtması da sanal gerçeklik teknolojisinin kullanımına benzetilebilmektedir. Sinemanın bir illüzyon olduğunun altı çizilerek, sanal gerçeklik de bu kapıdan içeri girip izleyicisinden bakılmasını istediği noktaya yönlendirmektedir. İzleyiciden şüpheciliğini bir kenara bırakarak içeri girmesini isteyen sanal gerçeklik, bunu kullanarak gerçeklik algısını da arttırmayı amaçlamaktadır. Korku filmleri özelinde incelenen sanal gerçeklik ve The Conjuring 2: VR Experience ile The Forest - 360 Experience örneklerine bakıldığında, örneklerin yıl itibariyle filmlerin pazarlanması olarak kullanılmaya başlanmasına rağmen kendi başlarına birer film öğelerinin taşıdıkları görülmektedir. Bu sayede yapılan film incelemelerinde korku sinema anlatılarından da yararlanıldığı planlarla 
birlikte gerçeklik kavramı birleştirilerek izleyenlerin gerçeklik kavramı bulanıklaştırılarak onları filmlere dahil etmektedirler. Göstergebilimle birlikte yapılan çözümlemelerde bu VR örneklerinin korku ve gerçeklik öğelerinin göstergeleri incelenerek ortaya konulmaktadır. Çalışma kapsamında ortaya çıkarılan en belirgin öğelerden bir diğeri de, filmin öznesi artık izleyenlerdir. Filmin devamlılığı izleyicinin yönlendirmeleri, bakış yönleri ve olay örgüsüne göre imkan dahilindeki tepkilerine bağlıdır. Filmin üretim süreci bir ekip işi olmasına rağmen, filmin devamlılığı izleyicisinin sorumluluğuna girmektedir. Sanal gerçeklik ve sinemanın birlikte henüz yeni sayılabilecek örnekler ortaya koymaya başladıkları kabul edilebilir. Bu yeni birliktelik, birbirlerinin özelliklerinden yararlanarak birbirlerini geliştirmeye de devam edeceklerdir.

EXTENDED ABSTRACT: Virtual Reality is a simulated computer technology experience that can be similar to or completely different from the real world. Virtual reality has a presence in various fields from tourism to entertainment, from the design of architectural structures to art tours, thanks to applications using its infrastructure. Technological developments in recent years and the fact that VR products are suitable for home users increase the interest in virtual reality. The obscurity and the scarcity of studies on this new partnership between cinema and VR constitute the important part of the study. This study aims to analyze both of the horror VR movies The Conjuring 2: VR Experience and The Forest - 360 Experience by following the traces of virtual reality in cinema. In the analysis which will be carried out by making use of semiotics, the perception of fear in the cinema Sayfa | 1188 by the audience will be discussed by considering the psychology aspect. Cinema has an own language. There are no doubt the images in this language. Semiotics is used to examine the images and to make their real and connotative meanings visible. Some questions that are tried to be answered within the scope of the study are determined before the study. These questions are how VR technology affects cinema; it seeks answers to the process of the development of the partnership between cinema and VR; and what kind of reflections they create in films, based on the relationship between reality, realism and cinema. For the study, the development of virtual reality, understanding of its technological infrastructure, its relationship with cinema, horror and reality in cinema, realism and cinema are used in the study by reaching domestic and foreign resources. In the first part of the study, virtual reality is defined and explained. By referring to its historical development in this section, the expansion of the usage area with the development process and its relationship with cinema are discussed. Theoretical approaches and discussions are explained before the analysis, by giving the opinions in the literature about the studies on reality, realism and cinema. Then, because of the sample films are in the horror genre, the basis for the analysis is created by referring to the relationship between cinema and fear. When it comes to the analysis part, the stories of the films are mentioned together with their technical information. Producer companies, duration and stories of the samples can provide details in the review of samples. According to the places where the stories take 
place, cultural and sociological elements can be searched more carefully. All details are important for the analysis of the signs. Semiotics is used to analyze the signs collected from the samples. By selecting the images, Roland Barthes' interpretation and Ferdinand de Saussure's understanding of signs are based on and the meanings produced by the signs are tried to be analyzed and interpreted. Within the scope of this study, which examined virtual reality in the context of cinema; the fact that cinema reflects reality with its own elements from the point it has reached can also be compared to the use of virtual reality technology. Cinema is an illusion, virtual reality enters through this door and directs the viewer to the point where it wants to be looked at. Virtual reality, which asks the audience to leave their skepticism aside and enter, aims to increase the perception of reality by using it. When we look at the examples of virtual reality and The Conjuring 2: VR Experience and The Forest - 360 Experience, which are examined specifically for horror movies, it is seen that although the examples have started to be used as the marketing of movies as of that year, they carry movie elements on their own. In the movie reviews, the concept of reality is combined with the plans in which horror cinema narratives are also used and the reality concept of the viewers is blurred and they include them in the movies with this way. In the analyzes made with semiotics, the signs of the fear and reality elements of these VR examples are revealed by examining them. Another of the most prominent elements revealed within the scope of the study is that the subject -hero- of the film is now the audience. The continuity of the film depends on the audience's directions, sight Sayfa | 1189 sides and possible reactions to the story line. Although the production process of the film is a team effort, the continuity of the film is the responsibility of the viewer. It can be accepted that virtual reality and cinema have started to present examples that can be considered new. This new union will continue to develop each other by taking advantage of each other's features. 